\section{Pacific Northwest}

National Laboratory

Operated by Battelle for the

U.S. Department of Energy

\title{
Impact of the FY 2005 Building Technologies Program on United States Employment and Earned Income
}

\author{
M. J. Scott \\ J.A. Dirks \\ D.M. Anderson \\ D. B. Elliott \\ D.B Belzer \\ D. J. Hostick \\ K.A. Cort
}

August 2004

Prepared for the U.S. Department of Energy

under Contract DE-AC06-76RL01830 


\title{
DISCLAIMER
}

This report was prepared as an account of work sponsored by an agency of the United States Government. Neither the United States Government nor any agency thereof, nor Battelle Memorial Institute, nor any of their employees, makes any warranty, express or implied, or assumes any legal liability or responsibility for the accuracy, completeness, or usefulness of any information, apparatus, product, or process disclosed, or represents that its use would not infringe privately owned rights. Reference herein to any specific commercial product, process, or service by trade name, trademark, manufacturer, or otherwise does not necessarily constitute or imply its endorsement, recommendation, or favoring by the United States Government or any agency thereof, or Battelle Memorial Institute. The views and opinions of authors expressed herein do not necessarily state or reflect those of the Untied States Government or any agency thereof.

\author{
PACIFIC NORTHWEST NATIONAL LABORATORY \\ operated by \\ BATTELLE \\ for the \\ UNITED STATES DEPARTMENT OF ENERGY \\ under Contract DE-AC06-76RL01830
}

This document was printed on recycled paper.

(9/2003) 
PNNL-14813

\title{
Impact of the FY 2005 Building Technologies Program on United States Employment and Earned Income
}

\author{
M. J. Scott \\ J.A. Dirks \\ D.M. Anderson \\ D. B. Elliott \\ D.B Belzer \\ D. J. Hostick \\ K.A. Cort
}

August 2004

Prepared for

the U.S. Department of Energy

under Contract DE-AC06-76RL01830

Pacific Northwest National Laboratory

Richland, Washington 99352 


\begin{abstract}
The Department of Energy (DOE) Office of Energy Efficiency and Renewable Energy (EERE) is interested in assessing the potential economic impacts of its portfolio of subprograms on national employment and income. A special purpose version of the IMPLAN input-output model called ImBuild II is used in this study of all 21 Building Technologies Program subprograms in the EERE final FY 2005 budget request to the Office of Management and Budget on February 2, 2004. Energy savings, investments, and impacts on U.S. national employment and earned income are reported by subprogram for selected years to the year 2030. Energy savings and investments from these subprograms have the potential of creating a total of 396,000 jobs and about $\$ 5.6$ billion in earned income (2003\$) by the year 2030.
\end{abstract}




\section{Summary}

As part of measuring the impact of government programs for improving the energy efficiency of the nation's building stock, the Department of Energy (DOE) Office of Energy Efficiency and Renewable Energy (EERE) is interested in assessing the economic impacts of its portfolio of subprograms, specifically the potential impact on national employment and income. This assessment was done for the first time in FY 1999 as a supplement to the Government Performance and Results Act (GPRAformerly, Quality Metrics) analysis for EERE. The GPRA analysis provides estimates of primary energy savings and environmental and direct financial benefits of the EERE Building Technologies Program. The current analysis relates to the FY2005 budget request from EERE.

The programmatic needs of EERE suggest that a simple, flexible, user-friendly method is needed to derive national employment and income impacts of individual EERE subprograms. Therefore, EERE funded Pacific Northwest National Laboratory (PNNL) to develop a special-purpose national input-output model called ImBuild, the latest version of which is ImBuild II (Scott et al. 2002). In this report, we use the ImBuild II model to calculate the impact of all 21 EERE Building Technologies Subprograms, based on the final Building Technologies Program budget submitted February 2, 2004.

EERE subprograms affect the economy through three primary mechanisms. First, if the incremental capital costs of the new technology per installed unit are different from those of the conventional technology, the level of purchases will change in the sectors involved in manufacturing, distribution, and installation for both technologies, changing the level of overall economic activity. Second, the efficiency investment may crowd out other domestic investments and consumer spending, offsetting some positive impact on the economy caused by the new efficiency investment. Third, energy expenditures are reduced, lowering final sales in the electric and gas utility sectors, as well as in the trade and services sectors that provide related maintenance, parts, and services. However, these savings are equivalent to increased income to households that, in turn, leads to increased spending across all sectors of the economy.

Energy efficient technology is expected to have a measurable effect on the activity level of the U.S. economy. EERE subprograms generally are characterized by significant investment requirements and delivered energy cost savings. The Building Technologies Program consists of four planning units, each of which contains several specific subprograms: Residential Buildings, Commercial Buildings Integration, Emerging Technologies, and Equipment Standards and Analysis. The impacts of the Building Technologies Program are summarized in Figure S.1 and Table S.1. ${ }^{\text {a }}$ Figure S.1 and Table S.1 show the energy savings expected to be created by market penetration of these subprograms have the

\footnotetext{
${ }^{\text {a }}$ In this analysis, we used subprogram information developed as described in Elliott et al. (2004) that PNNL prepared in cooperation with EERE subprogram managers. Delivered energy is used to calculate potential savings resulting from reduced demand for electrical generating capacity and natural gas pipeline capacity. See Scott et al. (2002).
} 
potential of creating nearly 396,000 jobs and about $\$ 5.6$ billion in earned income (2003\$) by the year 2030. However, the net gains would be affected by the intensive investment in new energy technology and new building practices would be required during the first 30 years of the $21^{\text {st }}$ century. These effects are incorporated in the full investment scenario shown in the lower half of Table S.1. Because the Building Technologies Program investment tends to be concentrated in capital-intensive, high-wage industries, there is a slight net negative impact on employment and positive impact on earnings from this group of investments. Many of the capital investments required to achieve these savings begin early in the 30-year period.

To be in concert with a recent analysis of the Department of Energy's Energy Research and Development program by the National Research Council (NRC) of the National Academy of Sciences (NAS), the analysis in some cases only takes credit for the first three to ten years of market impact. The NRC used a simplifying assumption that government R\&D programs do no more than accelerate the technology, bringing it to market five years before the private sector would have without government intervention. The net effect of this assumption is that incremental investments and savings due to the Building Technologies subprograms are offset by investments and savings expected to occur without the program, which reduces the long-term impacts attributable to the Building Technologies subprograms. However, the analysis of Building Technologies subprograms performed for this report shows that the impacts on investment and energy savings result from the interaction of four factors: 1) the size of the (usually growing) market at each point in time, 2) the penetration rate for the EERE-developed technologies and practices, based on lifetime cost savings vis-à-vis conventional technology and the associated payback period for the investment, 3) increases in the efficiency per dollar of incremental investment, based in turn on the sales-volume based decline in the price of the technology and the higher durability of the Building Technologies Program technology compared to current technology, and 4) the market-transformation, crowding-out effects of one technology on market prospects of all of its potential competitors. This results in a "hill-like" pattern of subprogram-related efficiency investments shown in the upper left-hand panel of Figure S.1, and in Table S.1. 
Table S.1. Impact of the Building Technologies Program on the U.S. Economy

$\begin{array}{cccc}\begin{array}{c}\text { Incremental } \\ \text { Investment Cost } \\ \text { (Million 2003\$) }\end{array} & \begin{array}{c}\text { Delivered } \\ \text { Energy Saved } \\ \left(10^{12} \text { Btu) }\right.\end{array} & \begin{array}{c}\text { Potential } \\ \text { Jobs Created } \\ \text { (Thousands) }\end{array} & \begin{array}{c}\text { Impact on } \\ \text { National } \\ \text { Earnings } \\ \text { (Million 2003\$) }\end{array}\end{array}$

$\begin{array}{lrrrr}\begin{array}{l}\text { Impact of Energy Savings } \\ \text { Alone }\end{array} & & & \\ 2005 & 0 & 9 & 2 & \$ 25 \\ 2006 & 0 & 22 & 3 & \$ 42 \\ 2007 & 0 & 41 & 6 & \$ 73 \\ 2008 & 0 & 79 & 12 & \$ 152 \\ 2009 & 0 & 129 & 18 & \$ 237 \\ 2010 & 0 & 190 & 26 & \$ 335 \\ 2015 & 0 & 636 & 79 & \$ 1,023 \\ 2020 & 0 & 1,270 & 162 & \$ 2,122 \\ 2025 & 0 & 2,120 & 297 & \$ 3,892 \\ 2030 & 0 & 2,865 & 420 & \$ 5,487 \\ \text { Impact of Full Investment Scenario } & & & \\ 2005 & \$ 805 & 9 & 1 & \$ 56 \\ 2006 & \$ 1,285 & 22 & 1 & \$ 94 \\ 2007 & \$ 1,991 & 41 & 3 & \$ 148 \\ 2008 & \$ 6,844 & 79 & -3 & \$ 194 \\ 2009 & \$ 8,096 & 129 & 1 & \$ 320 \\ 2010 & \$ 12,018 & 190 & 2 & \$ 504 \\ 2015 & \$ 17,840 & 636 & 44 & \$ 1,377 \\ 2020 & \$ 16,217 & 1,270 & 129 & \$ 2,473 \\ 2025 & \$ 12,500 & 2,120 & 270 & \$ 4,123 \\ 2030 & \$ 10,752 & 2,865 & 396 & \$ 5,630\end{array}$



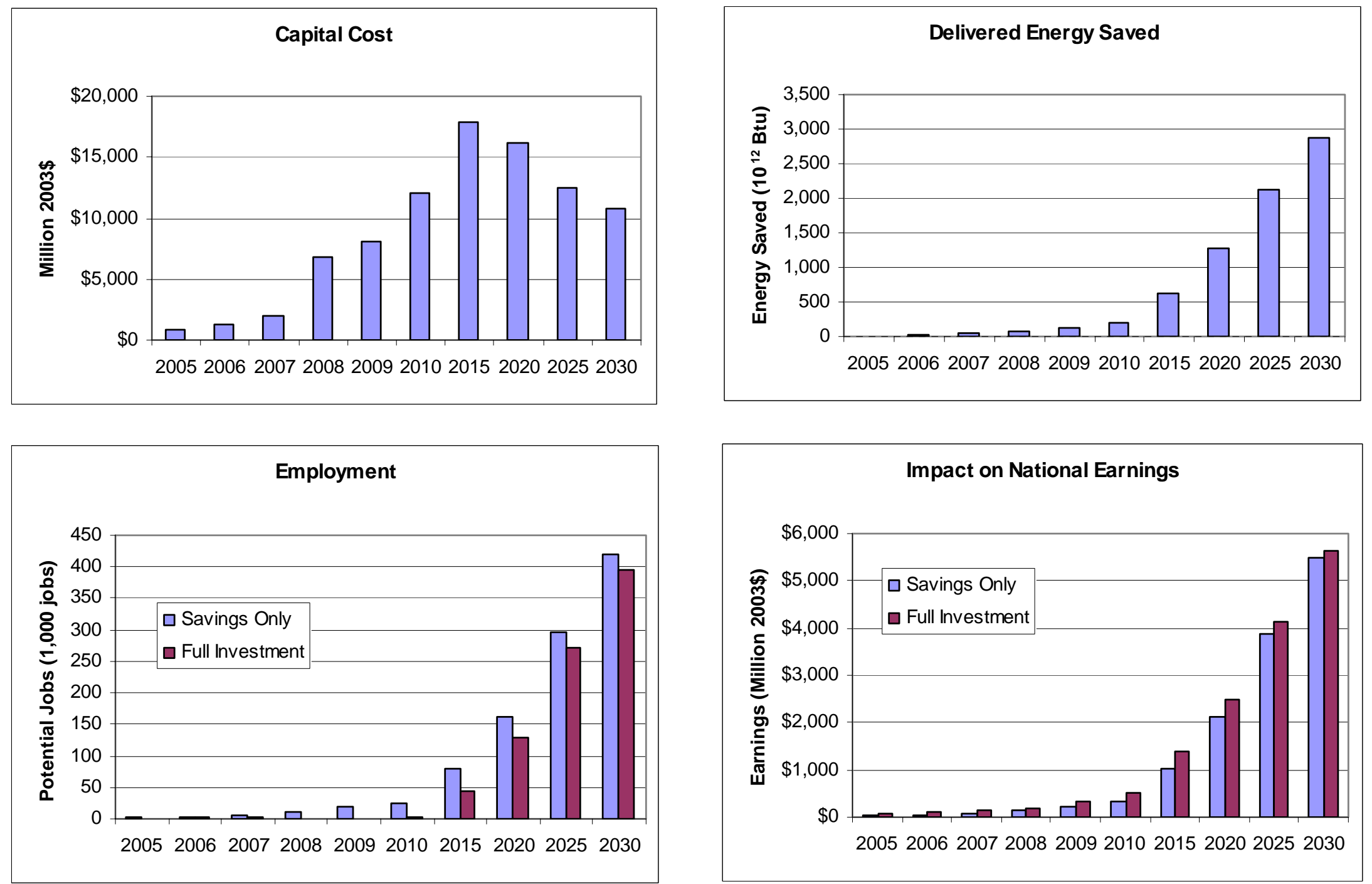

Figure S.1. Impact of the Building Technologies Program on the U.S. Economy 
Only when the energy benefits of cumulative efficiency investments have grown large, relative to the costs of current investment, would the full impacts on employment and income become visible. Thus, in the full investment scenario, as the energy technologies and practices associated with the Building Technologies subprograms penetrate the U.S. marketplace over the next 25 years, the required capital investments are significant and increasing over most of the period, reaching a peak of about $\$ 18$ billion per year in 2015. These required investments divert national spending into capital-intensive sectors and initially reduce employment below what it otherwise would have been. However, the energy savings associated with these same investments (2.9 quadrillion Btus per year by the year 2030, worth about \$61 billion) are true economic savings that provide new economic opportunities, generate ever-increasing numbers of jobs and higher income, and eventually become the dominant economic result of the Building Technologies Subprograms.

More than half of the net jobs and net earned income benefits of the Building Technologies Program come from only two of the subprograms: Residential Buildings R\&D (Building America) and Solid State Lighting. These two subprograms both are expected to produce large energy savings relative to the investments required. By the year 2030, these two subprograms will produce net annual savings to the U.S. economy (after investment costs) over $\$ 6.3$ billion per year and $\$ 23.1$ billion per year, respectively, and 49,000 and 173,000 net total jobs (after investment effects). The impacts of most of the other Building Technologies subprograms are on a much smaller scale. 


\section{Acronyms}

$\begin{array}{ll}\text { AC } & \text { air conditioning } \\ \text { CFL } & \text { compact fluorescent lamp } \\ \text { DOE } & \text { Department of Energy } \\ \text { EERE } & \text { Office of Energy Efficiency and Renewable Energy } \\ \text { EIA } & \text { Energy Information Administration } \\ \text { FY } & \text { fiscal year } \\ \text { GDP } & \text { Gross Domestic Product } \\ \text { GPRA } & \text { Government Performance and Results Act (formerly, Quality Metrics) } \\ \text { HPWH } & \text { heat pump water heater } \\ \text { HUD } & \text { Housing and Urban Development } \\ \text { HVAC } & \text { Heating, Ventilating and Air Conditioning } \\ \text { ImBuild } & \text { Special purpose version of IMPLAN (PNNL) } \\ \text { IMPLAN } & \text { Impact Analysis for Planning } \\ \text { NAS } & \text { National Academy of Sciences } \\ \text { NRC } & \text { National Research Council } \\ \text { PNNL } & \text { Pacific Northwest National Laboratory } \\ \text { R\&D } & \text { Research and Development } \\ \text { RIMS II } & \text { Regional Input-Output Modeling System } \\ \text { SIC } & \text { Standard Industrial Classification }\end{array}$




\section{Acknowledgments}

The authors would like to acknowledge Jerry Dion, formerly of the Department of Energy Office of Planning, Budget and Analysis, and now with the Building

Technologies Program, for support of the work discussed in this report. We would also like to acknowledge the assistance of several colleagues who reviewed and commented on the methodology and this report: A.K. Nicholls, S.C. McDonald, J.M. Roop, and S.A. Shankle. 


\section{Contents}

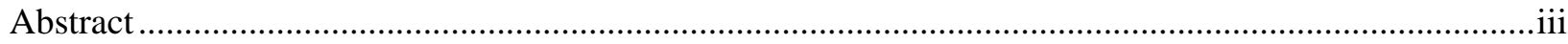

Summary

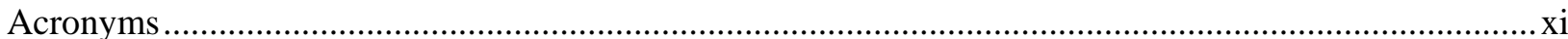

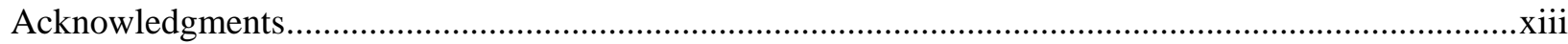

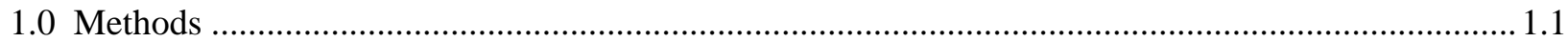

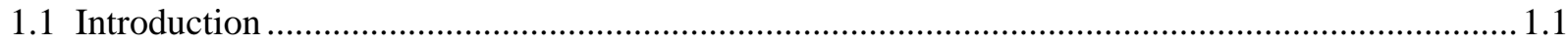

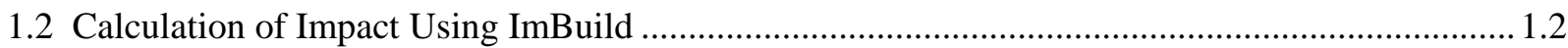

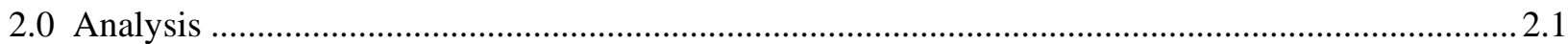

2.1 EERE Building Technologies Program.................................................................................... 2.1

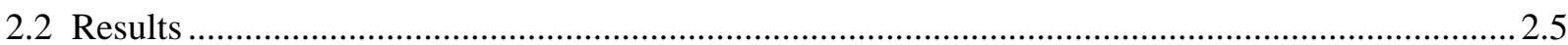

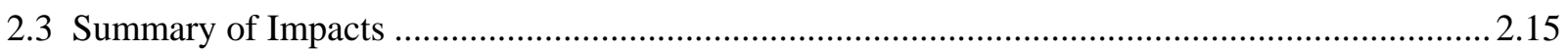

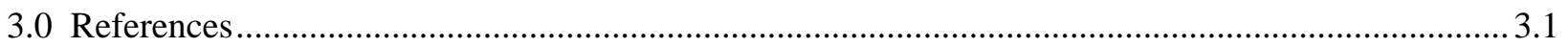

Attachment: Detailed Calculations on EERE Building Technologies Subprograms............................... A.1 


\section{Figures}

S.1 Impact of the Building Technologies Program on the U.S. Economy..................................... viii

1.1 Detailed Calculations of the ImBuild II Model ..........................................................................

1.2 Impact on National Employment of a Hypothetical Once-Only \$100 Million Investment in Appliance Efficiency

\section{Tables}

S.1 Impact of the Building Technologies Program on the U.S. Economy ….................................. vii

2.1 Investment Cost and Savings from EERE Building Technologies Subprograms

(Millions of 2003 Dollars)

2.2 Effect of Energy Savings from Building Technologies Subprograms on Potential National Employment

2.3 Effect of Energy Savings from Building Technologies Subprograms on Potential National Earned Income

2.4 Effect of the Full Investment Scenario on Potential National Employment .............................. 2.11

2.5 Effect of the Full Investment Scenario on Potential National Earned Income .......................... 2.13

A.1 Building Technologies Subprogram Investment Costs and Energy Savings, by Year .............. A. A.2

A.2 Building Technologies Subprogram Investment Costs by Sector.......................................... A.8 


\subsection{Methods}

\subsection{Introduction}

A primary goal of the Department of Energy (DOE) Office of Energy Efficiency and Renewable Energy (EERE) is to save energy. However, EERE projects also have economic impacts as energy investments, and the resultant savings in energy expenditures influences the national economy. As part of measuring the impact of government projects on improving the energy efficiency of the nation's building stock, EERE is interested in assessing the economic impacts of these projects, specifically the impact on national employment and earned income. As a consequence, EERE funded Pacific Northwest National Laboratory (PNNL) to develop a simple-to-use method that could be used in-house to estimate economic impacts of individual projects.

Three fundamental methods are available to estimate employment and earned income impacts for selected energy efficiency improvements in the U.S. economy: multipliers, input-output models, and macroeconomic simulation models. PNNL staff reviewed the EERE programmatic needs and available methods and, based on this assessment and on realistic resource constraints, designed and developed a

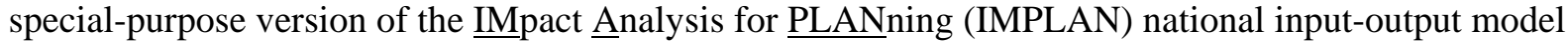
(Minnesota IMPLAN Group, Inc. 1997) specifically to estimate the employment and income effects of building energy technologies. IMPLAN was developed originally by the U.S. Forest Service in cooperation with the Federal Emergency Management Agency and the Bureau of Land Management to assist the Forest Service in land and resource management planning. Since 1979, it has been used by a wide variety of government and private agencies to assess economic impacts. The special-purpose version of the IMPLAN model developed by PNNL was called ImBuild. The version used in this study is called ImBuild II. Extensive documentation and a user's guide are provided in Scott et al. (2002), which discusses the methods, structure of the ImBuild II model, and its testing and performance. For a detailed discussion of the methodology used in this study, refer to that report.

Compared with simple economic multiplier approaches, such as the published multipliers from the Department of Commerce Regional Input-Output Modeling System (RIMS II) (Bureau of Economic Analysis 1992), ImBuild II allows for more complete and automated analysis of the economic impacts of energy efficiency investments in buildings. ImBuild II is also easier to use than extant macroeconomic simulation models. It does not include the ability to model certain dynamic features of markets for labor and other factors of production featured in these more complex models, but for most purposes these excluded features are not critical. Such impacts can be handled well by an input-output model and the analysis should be credible, as long as the assumption can be made that relative prices in the economy would not be substantially affected by energy efficiency investments. The expected scale of these investments is small enough in most cases that neither labor markets nor production cost relationships will seriously affect national prices as the investments are made. The exact timing of impacts on gross product, employment, and national earned income from energy efficiency investments is not well enough understood that much special insight can be gained from the additional dynamic sophistication of a macroeconomic simulation model. Thus, ImBuild II is a cost-effective compromise. 


\subsection{Calculation of Impact Using ImBuild}

As energy-efficient technologies penetrate the marketplace, EERE buildings-related projects will affect national employment and earned income. To analyze these effects, the ImBuild II model requires certain information on the projects: the size of the incremental investment in the technology over time compared with the conventional technology it replaces, corresponding energy savings by fuel in physical and monetary terms (which may include additional use of some fuels when one type of fuel replaces another), and non-energy operations savings (if any) in comparison with the current technology (Figure 1.1).

ImBuild II calculates changes in the use of energy, labor, and materials due to incremental investments and economic savings associated with EERE-supported technologies and practices, as shown in Figure 1.1. As the figure illustrates, new investments in these technologies affect the level of employment and earned income in the economy by multiple pathways. First, the manufacture and installation of this equipment creates jobs and income in some industries, while diverting funds that otherwise would have been spent for other goods and services by businesses and households. At the same time, the investment in energy-efficient technologies or practices may make other investments in energy supply technologies (for example, power plants) unnecessary, directly and indirectly affecting jobs and income.

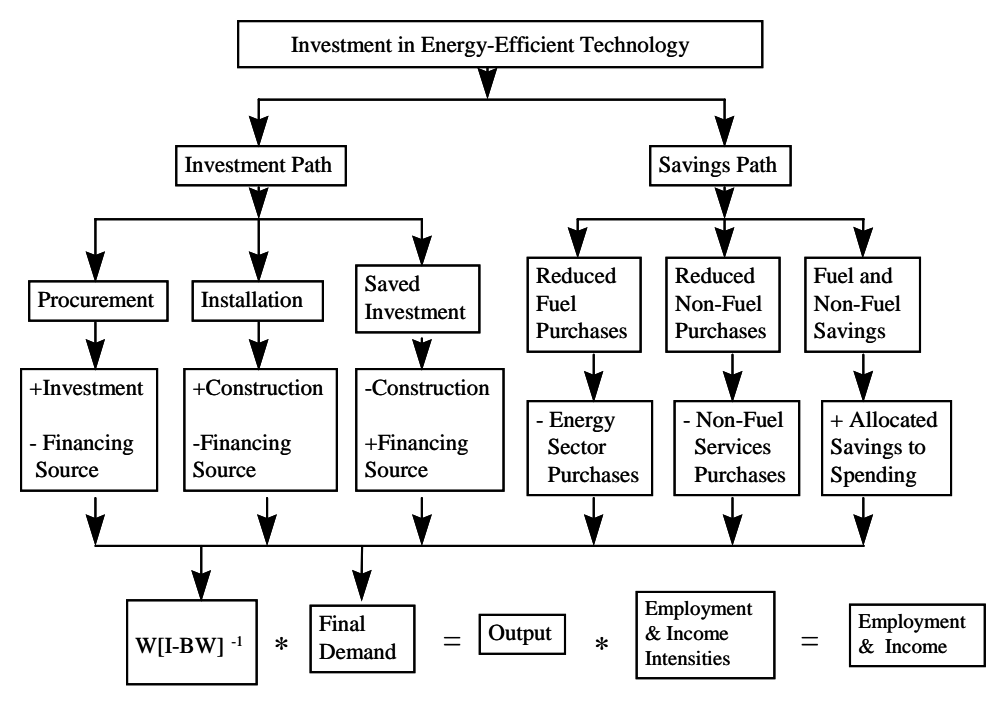

Figure 1.1. Detailed Calculations of the ImBuild II Model 
The issue is discussed in more detail in Scott et al. (2002). ${ }^{\text {a }}$ For this report, we assumed that financing for the energy-efficient investments is drawn proportionately from the rest of the U.S. economy. ${ }^{\text {b }}$ Figure 1.1 also shows that an investment in energy-efficient technology reduces the amount of energy needed. Reducing energy consumption reduces energy purchases (which in turn reduces employment and income in the energy-supplying sectors) and produces dollar savings that can be spent on any good or service, including energy (which creates employment and income). In addition, some energy efficiency investments may save the purchaser other costs such as maintenance services, and these savings also have impacts.

All of these pathways in Figure 1.1 either affect the interindustry intermediate procurement (the matrix W[I-BW] $]^{-1}$ in Figure 1.1) or the final demand (the set of goods and services in the economy purchased for final consumption or new investment, as distinguished from those purchased merely as intermediate inputs to current production). In residential applications, the necessary model calculations are relatively straightforward, because residential savings are assumed to be entirely recycled into personal consumption and investment (that is, final demand). For commercial building applications, the process is more complicated because the interindustry relationships between specific sectors are affected, not just final demand. For savings in the commercial sector, the interindustry portion of the input-output table is automatically recomputed; then the model is run with the recomputed table. Because the energy and maintenance intensity of the commercial sector changes, the coefficients of the input-output structure are automatically recalculated at each time step. The financial impacts of energy and non-energy cost savings (for example, savings in building maintenance) are computed by the model. These savings are treated like "free" income, available to be saved or invested by the sector collecting the income.

A brief hypothetical example from Scott et al. (2002) illustrates the concepts and functioning of the ImBuild II model. It is assumed that consumers spend a premium of \$100 million on more-efficient residential heating and air-conditioning equipment in the year 2000, which each year thereafter saves them \$15 million in electricity, \$30 million in natural gas, and \$5 million in building maintenance expenditures, for annual savings of $\$ 50$ million. This $\$ 50$ million annual savings yields a simple payback period of 2 years. The first two cases in Figure 1.2 show the employment effects of the $\$ 50$ million savings alone. In the first case, the savings are confined to the residential sector. The second case shows how the impacts would change if these energy savings had instead been experienced in the commercial sector, where the savings are initially experienced as an increase in the profitability of those businesses saving the energy.

\footnotetext{
${ }^{a}$ For this report, we estimated electric power plant construction savings at about $\$ 590 / \mathrm{kW}$ of delivered electric energy, based on data in EIA (2002) and the equivalent value for natural gas, about \$1.20/cubic foot/day capacity, based on EIA (1996) and EIA (1999). These values have not changes significantly in recent years.

${ }^{\mathrm{b}}$ It is assumed that personal (household) consumption represents $70 \%$ of spending; gross private fixed investment, $10 \%$; federal defense spending, $2 \%$; federal non-defense spending, $6 \%$; and state and local government spending, about $12 \%$. These percentages are close to the actual distribution of final demand among these sectors in the U.S. economy.
} 


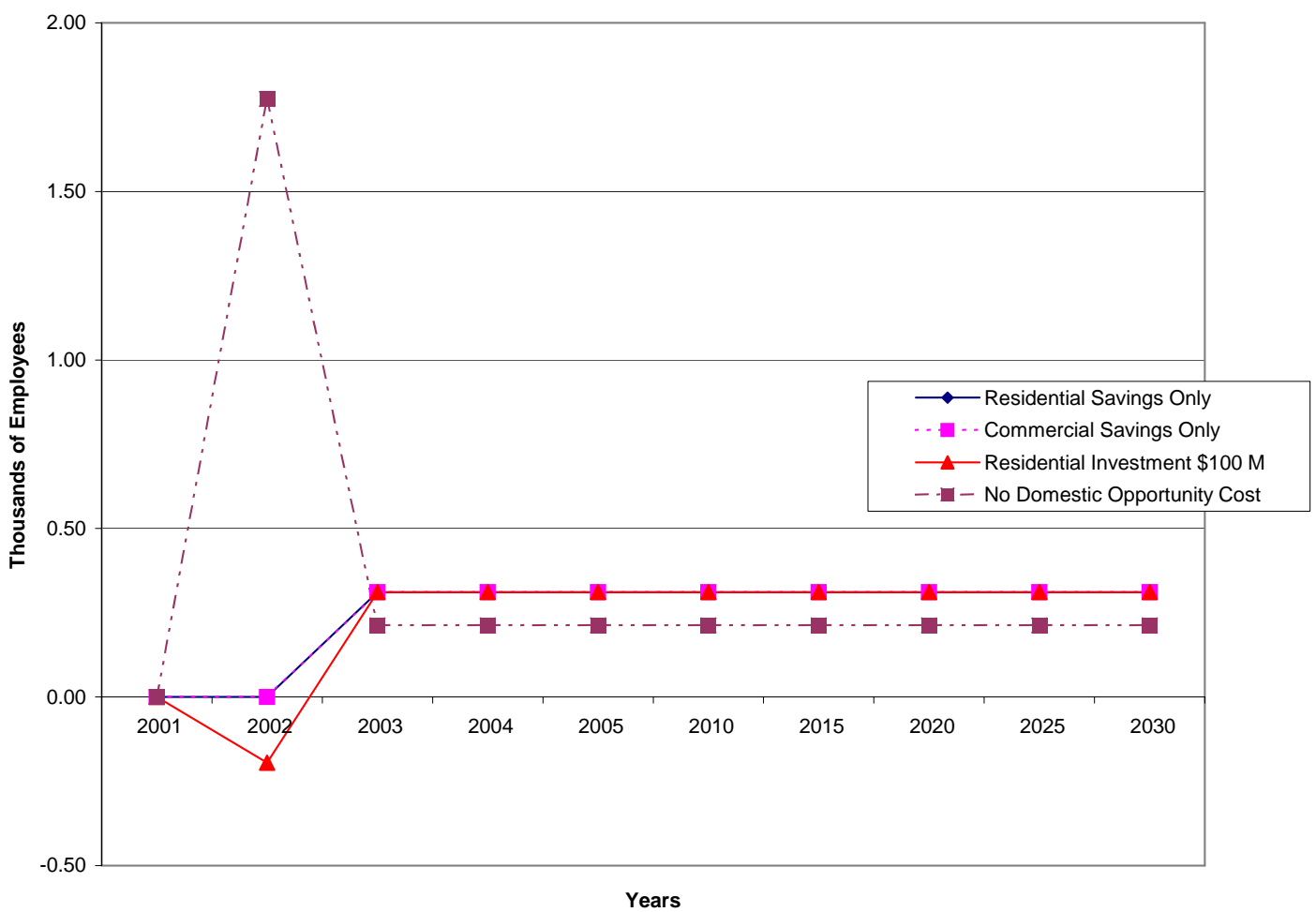

Figure 1.2. Impact on National Employment of a Hypothetical Once-Only $\$ 100$ Million Investment in Appliance Efficiency

These profits are assumed to be recycled in the economy as spending by workers, spending by the firms themselves, and by governments experiencing increases in tax collections. In the first case, the energy savings in the residential sector of \$50 million have a net impact on the U.S. economy of about 310 jobs, or about 0.6 additional jobs per $\$ 100$ thousand dollars of direct energy savings. The impact is virtually identical if the energy savings occur in the commercial sector, because the employment intensity of the spending mix of businesses, their workers, and government associated with commercial savings is only slightly different from the spending intensity of the household sector alone, which is associated with residential saving. Next, Figure 1.2 adds a third and fourth case to show the employment impacts of the $\$ 100$ million investment itself. The third case shows the impact of the investment premium. In this case, even though investment in the technology itself generates employment, the short run net employment impact is negative (minus 200 jobs) because the opportunity cost of the investment premium is the dollar amount the investment would have produced elsewhere in the U.S. economy, which on average is more labor-intensive than the manufacturing sector that makes the new technology. ${ }^{\text {a }}$ Typically, efficiency projects are considered relatively labor-intensive, but this is not always the case. Heating and air conditioning manufacture, for example, is quite capital-intensive. The strength and direction of the investment effect depends on the size of the investment premium and its combined domestic U.S. direct

aStrictly speaking, the labor intensity that counts is the employment, direct and indirect, that is created by each dollar of spending. Thus, it is theoretically possible for a capital-intensive industry to buy lots of labor-intensive inputs from other industries and the total effect to be labor intensive as a result. 
and indirect labor intensity, relative to that of other domestic spending (the opportunity cost of the investment). For the employment impact of the investment to be positive, the sectors supplying the new technology must on average create more domestic jobs per dollar of spending than does other domestic spending. An extreme form of this positive investment effect would occur, if the investment were financed internationally (that is, no domestic opportunity cost is included). This is the fourth case in Figure 1.2, which shows a short-run jobs impact of more than 1770 and a long-run jobs impact of 210. The fourth case also corresponds to many regional analyses that have been made of energy conservation impacts, where the investment funds are assumed to come from somewhere else and have no opportunity cost in the region.

The energy and non-energy savings from installation of efficient technology do not affect employment in the national economy until reinvested or spent. For purposes of the analysis conducted for this report, we assume that any increments to the economic value-added in each sector as a result of the investment (that is, the energy and non-energy savings) are allocated to compensation of labor, capital, and business taxes in the same proportions as all other value-added ${ }^{\mathrm{b}}$ in that sector. The income of each sector then is assumed to be spent on investment and consumption of goods and services (final demand) in the same proportions as existing compensation of labor, capital, and government. That is, if a given sector captures $1 \%$ of all personal consumption expenditures in the economy and a $0.7 \%$ share of all business fixed investment, it will receive these same percentage shares of the efficiency-related increase in spending. Similarly, if labor compensation represents $70 \%$ of the baseline total value added in an industry, it will receive $70 \%$ of any energy savings in that industry. Finally, labor compensation, business profits and taxes are allocated to consumption, investment, and government spending, according to current proportions.

ImBuild accumulates the energy and non-energy savings in the residential buildings sector and the changes in economic value-added associated with energy and non-energy savings within the commercial buildings sector. The model then calculates spending impacts associated with these savings by proportionately increasing final demand across all sectors as noted previously, while at the same time reducing final demand in the sectors supplying the resources that are saved. This step accounts for the spending associated with the monetary savings and improvements in technological efficiency and for the associated shift from energy to non-energy spending. It also accounts for changes in the patterns of activity in the economy due to technological change caused by the EERE projects (that is, less electricity is used per dollar of output in retailing because of more efficient lighting) ${ }^{\mathrm{C}}$

\footnotetext{
${ }^{b}$ Economic value-added is the value of output of the sector, less the cost of purchased materials and services. The sum of value-added in all sectors is Gross Domestic Product (GDP). ${ }^{\mathrm{c}}$ ImBuild does not account for all of the long-term run impacts of the technological change. The change in energy-using capital in the commercial sector would alter the marginal value of all of the factors of production (including both labor and capital) and would induce a rearrangement of capital and labor that would ultimately result in an increase in output and in final demand. We show the multiplier effect created by spending of the energy and non-energy savings, but not the productivity effect of increased capital stock that would be created by the investment portion of the spending. Most economic models, including many dynamic simulation models, do not completely reflect the effect of capital accumulation and growth in capacity on final output and employment.
} 
ImBuild collects the estimates of the initial investments, energy and non-energy savings, and economic activity associated with spending of the savings (increases in final demand in personal consumption, business investment, and government spending), and provides overall estimates of the increase in national output for each economic sector using the adjusted input-output matrix. Finally, the model applies estimates of employment and earned income per dollar of economic output for each sector and calculates impacts on national employment and earned income. 


\subsection{Analysis}

\subsection{EERE Building Technologies Program}

This analysis encompasses the EERE Building Technologies subprograms that were evaluated for Fiscal Year 2005 in response to the Government Performance and Results Act (GPRA). Table 2.1 shows the level of incremental residential and commercial investments and net energy savings in the selected years 2005, 2010, 2020, and 2030 for the buildings-related subprograms that were evaluated. Each subprogram is designated with a numerical subprogram code to ensure ease in numerical modeling and for tracing a given subprogram as it undergoes periodic name changes. It is important to note that the values in Table 2.1 represent levels of current investment and energy and non-energy savings in the year shown. It is current investment and current energy and non-energy savings that determine the impact on employment and earned income. Reported in this way, the values in Table 2.1 cannot be used to determine a rate of return on any particular investment because an investment in a given year provides a stream of savings over several years, and the energy savings experienced in any particular year are a function of the cumulative previous investment in energy efficiency. The investment and energy savings levels in a given year affect the level of GDP in that year, in turn affecting the level of national employment and earned income. Although the subprograms differ from each other in size and timing, for the most part the annual investment exceeds the annual savings early in the period, and savings tend to dominate later on. In a few cases, the early investments are expected to be so durable and to fall so much in cost that the later years show investment savings vis-à-vis conventional technology.

The differences in investment reflect differences identified by the analysis as the size of the potential market opportunity or market niche for each subprogram, differences in the expected rate of market penetration into each niche, and differences concerning the incremental cost of the new technologies and practices penetrating the market, compared to the more conventional technologies or practices that they replace. Because investments occur over a period of years, the savings in any particular year do not necessarily correlate well with the investment in that year. Some technologies and practices are expected to generate relatively large energy savings and require relatively little incremental investment, while others require relatively more incremental investment or generate fewer savings. Generally, net energy expenditure is reduced, but reduced spending for one fuel (e.g., electricity for lighting) can result in slightly more expenditure for another (e.g., natural gas for heating) due to building system effects, as described in Appendix A. Savings are also sensitive to timing. For example, some subprograms like Commercial Building Energy Codes are expected to be still in the midst of their intensive incremental investment phase in the year 2030 (codes affect building investment patterns for a long time), while others like Solid State Lighting are expected to have come down in price to be competitive with the older technology and are enjoying pure savings by that date. For Building Technologies Subprogram details, refer to the GPRA documentation report (Elliott et al. 2004).

Many of the EERE Building Technologies Subprograms have increasing market penetration and investment levels through the year 2030. Thus, the energy savings levels for many of the subprograms are expected to increase after 2030. By the end of the period shown in Table 2.1, total annual savings have substantially exceeded total annual investments, and are continuing to accelerate. Investments as a group have begun to flatten out by 2020. Some of the incremental adoption of the technologies and the 
energy investments due to the subprograms accelerates an adoption process that would have occurred later, anyway. Incremental investments due to these EERE subprograms are overtaken by "normal" investments in the space of three to ten years, depending on the subprogram. In Table 2.1, this situation is reflected as negative investment in years toward the end of the analysis period. In other cases, it can be argued that the technology or practice never would have been developed without the EERE subprogram; therefore, the investment and savings would not have been overtaken in the marketplace. For details, see Elliott et al. (2004). 
Table 2.1. Investment Cost and Savings from EERE Building Technologies Subprograms (Millions of 2003 Dollars)

\begin{tabular}{|c|c|c|c|c|}
\hline & 2005 & 2010 & 2020 & 2030 \\
\hline \multicolumn{5}{|c|}{ 1. Residential Buildings } \\
\hline 115 & \multicolumn{4}{|c|}{ Research \& Development (Building America) } \\
\hline Investment & $\$ 219.9$ & $\$ 1,551.2$ & $\$ 1,699.8$ & $\$ 1,812.9$ \\
\hline Savings & $\$ 14.3$ & $\$ 368.0$ & $\$ 3,145.6$ & $\$ 8,140.9$ \\
\hline 506 & \multicolumn{4}{|c|}{ Residential Building Energy Codes } \\
\hline Investment & $\$ 0.0$ & $\$ 121.8$ & $\$ 284.5$ & $\$ 304.4$ \\
\hline Savings & $\$ 0.0$ & $\$ 78.5$ & $\$ 749.0$ & $\$ 1,568.2$ \\
\hline \multicolumn{5}{|c|}{ 2. Commercial Buildings Integration } \\
\hline 124 & \multicolumn{4}{|c|}{ Research \& Development } \\
\hline Investment & $\$ 123.0$ & $\$ 4,054.1$ & $\$ 2,076.8$ & $-\$ 118.8$ \\
\hline Savings & $\$ 3.8$ & $\$ 192.9$ & $\$ 1,433.7$ & $\$ 1,589.5$ \\
\hline 507 & \multicolumn{4}{|c|}{ Commercial Building Energy Codes } \\
\hline Investment & $\$ 0.0$ & $\$ 49.1$ & $\$ 326.0$ & $\$ 353.3$ \\
\hline Savings & $\$ 0.0$ & $\$ 22.1$ & $\$ 976.7$ & $\$ 1,453.3$ \\
\hline \multicolumn{5}{|c|}{ 3. Emerging Technologies } \\
\hline 430 & \multicolumn{4}{|c|}{ Lighting R\&D } \\
\hline 4304 & \multicolumn{4}{|c|}{ Lighting R\&D: Controls } \\
\hline Investment & $\$ 63.1$ & $\$ 102.0$ & $\$ 97.7$ & $\$ 98.9$ \\
\hline Savings & $\$ 21.8$ & $\$ 146.5$ & $\$ 535.1$ & $\$ 868.4$ \\
\hline 440 & \multicolumn{4}{|c|}{ Solid State Lighting } \\
\hline Investment & $\$ 0.0$ & $\$ 4.7$ & $\$ 43.5$ & $-\$ 124.9$ \\
\hline Savings & $\$ 0.0$ & $\$ 1.0$ & $\$ 2,334.0$ & $\$ 23,025.3$ \\
\hline 380 & \multicolumn{4}{|c|}{ Space Conditioning \& Refrigeration R\&D } \\
\hline 3801 & \multicolumn{4}{|c|}{ Refrigeration R\&D: Res. HVAC Dist. System } \\
\hline Investment & $\$ 0.0$ & $\$ 15.5$ & $\$ 76.8$ & $-\$ 67.1$ \\
\hline Savings & \multirow{2}{*}{\multicolumn{4}{|c|}{ 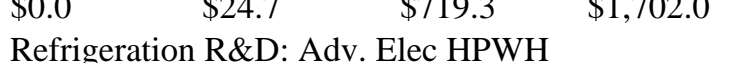 }} \\
\hline 3802 & & & & \\
\hline Investment & $\$ 3.1$ & $\$ 54.3$ & $\$ 296.7$ & $\$ 29.9$ \\
\hline Savings & $\$ 1.4$ & $\$ 60.3$ & $\$ 898.0$ & $\$ 551.9$ \\
\hline 3803 & \multicolumn{4}{|c|}{ Refrigeration R\&D: Commercial Refrigeration } \\
\hline Investment & $\$ 18.0$ & $\$ 58.0$ & $-\$ 22.5$ & $-\$ 33.8$ \\
\hline Savings & $\$ 8.0$ & $\$ 83.5$ & $\$ 366.8$ & $\$ 34.3$ \\
\hline $3804^{\circ}$ & \multicolumn{4}{|c|}{ Refrigeration R\&D: Refrigerant Meter } \\
\hline Investment & $\$ 4.3$ & $\$ 73.7$ & $\$ 413.8$ & $\$ 44.4$ \\
\hline Savings & $\$ 2.5$ & $\$ 103.8$ & $\$ 1,527.7$ & $\$ 1,101.7$ \\
\hline 381 & \multicolumn{4}{|c|}{ Appliances \& Emerging Technologies R\&D } \\
\hline 3811 & \multicolumn{4}{|c|}{ Appliances \& Emerging Tech R\&D: HPWH } \\
\hline Investment & $\$ 23.2$ & $\$ 139.9$ & $\$ 95.4$ & $\$ 101.3$ \\
\hline Savings & $\$ 33.0$ & $\$ 281.1$ & $\$ 864.3$ & $\$ 1,269.5$ \\
\hline 3813 & \multicolumn{4}{|c|}{ Appliances \& Emerging Tech R\&D: Roof Top AC } \\
\hline Investment & $\$ 13.8$ & $\$ 8.7$ & $\$ 8.5$ & $\$ 7.7$ \\
\hline Savings & $\$ 5.7$ & $\$ 21.4$ & $\$ 36.6$ & $\$ 50.7$ \\
\hline 3816 & \multicolumn{4}{|c|}{$\begin{array}{l}\text { Appliances \& Emerging Tech R\&D: Recessed Can } \\
\text { Lights }\end{array}$} \\
\hline
\end{tabular}




\begin{tabular}{|c|c|c|c|c|}
\hline & 2005 & 2010 & 2020 & 2030 \\
\hline Investment & $\$ 1.4$ & $\$ 9.1$ & $\$ 0.0$ & $\$ 0.0$ \\
\hline Savings & $\$ 2.3$ & $\$ 72.5$ & $\$ 117.2$ & $\$ 118.9$ \\
\hline 3817 & \multicolumn{4}{|c|}{ Appliances \& Emerging Tech R\&D: R-Lamp } \\
\hline Investment & $\$ 0.8$ & $\$ 1.0$ & $\$ 0.0$ & $\$ 0.0$ \\
\hline Savings & $\$ 32.7$ & $\$ 291.2$ & $\$ 0.4$ & $\$ 0.0$ \\
\hline 2111 & \multicolumn{4}{|c|}{ Building Envelope R\&D: Window Technologies } \\
\hline 2114 & \multicolumn{4}{|c|}{ Window Technologies: Electrochromic Windows } \\
\hline Investment & $\$ 0.0$ & $\$ 291.1$ & $\$ 2,337.2$ & $\$ 1,828.2$ \\
\hline Savings & $\$ 0.0$ & $\$ 4.0$ & $\$ 650.2$ & $\$ 2,877.7$ \\
\hline 2115 & \multicolumn{4}{|c|}{ Window Technologies: Superwindows } \\
\hline Investment & $\$ 0.0$ & $\$ 471.3$ & $\$ 2,518.4$ & $\$ 772.7$ \\
\hline Savings & $\$ 0.0$ & $\$ 70.8$ & $\$ 1,479.6$ & $\$ 3,363.9$ \\
\hline 2119 & \multicolumn{4}{|c|}{ Window Technologies: Low-E Market Acceptance } \\
\hline Investment & $\$ 66.8$ & $\$ 203.7$ & $\$ 0.0$ & $\$ 0.0$ \\
\hline Savings & $\$ 40.5$ & $\$ 766.6$ & $\$ 2,995.1$ & $\$ 3,417.5$ \\
\hline 145 & \multicolumn{4}{|c|}{ Analysis Tools and Design } \\
\hline Investment & $\$ 63.1$ & $\$ 523.3$ & $\$ 782.4$ & $\$ 699.9$ \\
\hline Savings & $\$ 2.2$ & $\$ 85.0$ & $\$ 573.6$ & $\$ 1,118.0$ \\
\hline \multicolumn{5}{|c|}{ 4. Equipment Standards and Analysis } \\
\hline 603 & \multicolumn{4}{|c|}{ Equipment Standards and Analysis } \\
\hline 6043 & \multicolumn{4}{|c|}{ Standards: Res. Gas Furnaces/Boilers } \\
\hline Investment & $\$ 0.0$ & $\$ 26.4$ & $\$ 5.8$ & $-\$ 0.4$ \\
\hline Savings & $\$ 0.0$ & $\$ 42.4$ & $\$ 278.8$ & $\$ 562.7$ \\
\hline 6044 & \multicolumn{4}{|c|}{ Standards: EPAct Standards } \\
\hline Investment & $\$ 205.0$ & $\$ 1,072.1$ & $\$ 1,473.7$ & $\$ 627.7$ \\
\hline Savings & $\$ 29.8$ & $\$ 550.5$ & $\$ 2,578.1$ & $\$ 3,443.3$ \\
\hline 6039 & \multicolumn{4}{|c|}{ Standards: Distribution Transformers } \\
\hline Investment & $\$ 0.0$ & $\$ 3,187.0$ & $\$ 3,767.2$ & $\$ 4,415.9$ \\
\hline Savings & $\$ 0.0$ & $\$ 474.2$ & $\$ 2,311.9$ & $\$ 4,574.3$ \\
\hline \multicolumn{5}{|c|}{ Building Technologies Program } \\
\hline Investment & $\$ 805.4$ & $\$ 12,017.8$ & $\$ 16,216.7$ & $\$ 10,752.2$ \\
\hline Savings & $\$ 197.9$ & $\$ 3,741.1$ & $\$ 24,148.4$ & $\$ 60,832.0$ \\
\hline
\end{tabular}




\subsection{Results}

The investments and energy savings attributable to the penetration of EERE Building Technologies Subprograms in the marketplace will result in substantial macroeconomic effects. The following tables summarize these effects. Table 2.2 shows the impact of the energy savings alone on potential national employment on a subprogram-by subprogram basis. The employment effects are called potential here because this estimate is really of the change in demand for workers. Actual employment effects could include changes in wage rates and also would be affected by changes in labor supply conditions. Table 2.3 shows the comparable effects on national earned income. Before accounting for investment costs, the effects of savings alone in the year 2030 are an increase of about 420,000 potential jobs and almost $\$ 5.5$ billion in national earned income.

As was previously discussed, obtaining these energy savings benefits requires a substantial national investment in energy efficient technologies and practices. For the most part, this incremental national investment will be made in manufacturing sectors that are relatively capital intensive to produce new and better equipment. We assume the source of the investment capital will be the U.S. economy as a whole, which is less capital intensive on average than is manufacturing. Just as in the example in Figure 1.2, most of the energy efficiency investments will tend to reduce national employment while they are occurring, because they divert investment into capital-intensive sectors. Therefore, Table 2.4, which combines the employment effects of the required energy efficiency investments and the employment effects of the required savings, shows lower employment impacts than does Table 2.2, which includes only the effects of the energy and non-energy savings and ignores the investment effects. By 2030, Table 2.4 shows potential net employment increases of about 396,000 jobs, about 94 percent of level in Table 2.2. Comparing the effects on national earned income in Tables 2.3 and 2.5 produces a similar but slightly more mixed picture. The net effect on earned income of the required investment, combined with the effect of resulting energy and non-energy savings, is a mixed effect because many of the jobs created in the capital-intensive manufacturing sectors as a result of Building Technologies Program-related investments are also high-wage jobs. This tends to compensate to some degree for the reduction in overall employment levels associated with the diversion of national spending into capital-intensive manufacturing activity. By 2030, Table 2.5 shows a potential net positive impact on national earned income of over $\$ 5.6$ billion, about three percent higher than the level in Table 2.3.

The impacts on investment and energy savings result from the interaction of four factors: 1) the size of the (usually growing) market at each point in time, which results in increasing investment and savings, 2) the increasing penetration rate for the EERE technologies and practices, based on lifetime cost savings vis-à-vis conventional technology and the associated payback period for the investment, which results in increasing investments and savings, 3) increases in the efficiency of a dollar of incremental investment, based in turn on the sales-volume-based rate of decline in the price of the technology and the higher durability of the EERE technology, which can considerably reduce investment even as the savings hold constant or increase, and 4) the market-transformation, crowding-out effects of one technology on market prospects of all of its potential competitors, which increases investment and savings due to the EERE subprogram. Even in those cases where the EERE subprogram mainly accelerates market adoption of 
efficient technologies, it is usually assumed that the adoption is accelerated by ten years. Combined with the long lead times required to introduce commercial versions of technologies to the marketplace and generally slow turnover rates of building stock, the result is that many technologies are still in the rapidly increasing market penetration phase of adoption in 2030. See Elliott et al. (2004) for methodological assumptions.

The individual Building Technologies Subprograms differ significantly from each other in scale, timing, and impact. Taking investment effects into account, more than 50 percent of the positive job and earnings impacts come from only two subprograms: Residential Building Codes R\&D and Solid State Lighting. Together, they account for 51\% of the annual savings in 2030, 59\% of the net savings, 56\% of the net jobs, and $53 \%$ of the net earned income effects. These subprograms are subprograms that are expected to produce large energy savings relative to the investments required. The combined net annual savings from two subprograms is projected at over \$29 billion, even after investment costs in 2030 are subtracted. The savings alone from these subprograms generate an estimated 224,000 potential jobs (222,000 after investment effects).

The initial effect of the required investment is a short-run reduction in jobs and income in the economy, but the net effect is small. By the year 2005, the effects of energy savings already more than compensate for the effects of investment. Many of the EERE Building Technologies Subprograms will have achieved only part of their ultimate market penetration at the end of the period. However, the overall positive net impact on employment (396,000 jobs) and earned income ( $\$ 5.6$ billion) in the year 2030 still is a significant boost to the economy, an effect that would continue to grow after 2030 as savings increase and investments are completed. 
Table 2.2. Effect of Energy Savings from EERE Building Technologies Subprograms on Potential National Employment

\begin{tabular}{|c|c|c|c|c|c|c|c|c|c|c|c|}
\hline \multirow{2}{*}{ Code } & \multirow{2}{*}{ Descriptor } & \multicolumn{10}{|c|}{ Effect on Total National Employment (Thousands of Jobs) } \\
\hline & & 2005 & 2006 & 2007 & 2008 & 2009 & 2010 & 2015 & 2020 & 2025 & 2030 \\
\hline \multicolumn{12}{|c|}{ 1. Residential Buildings } \\
\hline 115 & Res. Technology Research \& Development & 0.1 & 0.3 & 0.5 & 0.9 & 1.5 & 2.3 & 9.2 & 19.9 & 34.2 & 51.7 \\
\hline 506 & Residential Building Codes & 0.0 & 0.0 & 0.0 & 0.1 & 0.3 & 0.5 & 2.2 & 4.4 & 6.7 & 9.1 \\
\hline \multicolumn{12}{|c|}{ 2. Commercial Buildings Integration } \\
\hline 124 & Com. Technology Development & 0.0 & 0.1 & 0.2 & 0.3 & 0.6 & 1.2 & 5.4 & 8.3 & 8.9 & 9.0 \\
\hline 507 & Commercial Building Codes & 0.0 & 0.0 & 0.0 & 0.0 & 0.1 & 0.2 & 1.6 & 3.8 & 6.7 & 10.0 \\
\hline \multicolumn{12}{|c|}{ 3. Emerging Technologies } \\
\hline 430 & Lighting R\&D & & & & & etails ir & 4304-4 & & & & \\
\hline 4304 & Lighting R\&D: Controls & 0.3 & 0.3 & 0.4 & 0.6 & 0.8 & 1.1 & 2.7 & 4.0 & 5.2 & 6.5 \\
\hline 440 & Solid State Lighting & 0.0 & 0.0 & 0.0 & 0.0 & 0.0 & 0.0 & 1.5 & 17.5 & 95.6 & 172.9 \\
\hline 380 & Space Conditioning and Refrigeration R\&D & \multicolumn{10}{|c|}{ Details in 3801-3804 } \\
\hline 3801 & Refrigeration R\&D: Res. HVAC Dist. System & 0.0 & 0.0 & 0.0 & 0.0 & 0.1 & 0.2 & 1.3 & 4.3 & 7.9 & 10.1 \\
\hline 3802 & Refrigeration R\&D: Adv. Elec. HPWH & 0.0 & 0.0 & 0.1 & 0.2 & 0.3 & 0.5 & 2.7 & 6.7 & 7.6 & 4.1 \\
\hline 3803 & Refrigeration R\&D: Commercial Refrigeration & 0.1 & 0.1 & 0.2 & 0.3 & 0.4 & 0.6 & 2.0 & 2.5 & 1.2 & 0.2 \\
\hline 3804 & Refrigeration R\&D: Refrigerant Meter & 0.0 & 0.1 & 0.1 & 0.3 & 0.5 & 0.8 & 4.5 & 11.4 & 14.0 & 8.2 \\
\hline 381 & Appliances \& Emerging Technologies R\&D & \multicolumn{10}{|c|}{ Details in $3811-3817$} \\
\hline 3811 & Appliances \& Emerging Tech R\&D: HPWH & 0.4 & 0.4 & 0.6 & 1.0 & 1.4 & 2.1 & 5.2 & 6.5 & 7.9 & 9.5 \\
\hline 3813 & Appliances \& Emerging Tech R\&D: Roof Top AC & 0.1 & 0.1 & 0.1 & 0.1 & 0.1 & 0.2 & 0.2 & 0.3 & 0.3 & 0.4 \\
\hline 3816 & Appliances \& Emerging Tech R\&D: Recessed Can Lights & 0.0 & 0.1 & 0.1 & 0.3 & 0.4 & 0.6 & 0.9 & 0.9 & 0.9 & 0.9 \\
\hline 3817 & Appliances \& Emerging Tech R\&D: R-Lamp & 0.4 & 0.7 & 1.2 & 1.9 & 2.2 & 2.2 & 0.3 & 0.0 & 0.0 & 0.0 \\
\hline 2111 & Building Envelope R\&D: Window Technologies & \multicolumn{10}{|c|}{ Details in 2114-2119 } \\
\hline 2114 & Window Technologies: Electrochromic Windows & 0.0 & 0.0 & 0.0 & 0.0 & 0.0 & 0.0 & 0.9 & 4.6 & 11.9 & 20.3 \\
\hline 2115 & Window Technologies: Superwindows & 0.0 & 0.0 & 0.0 & 0.1 & 0.2 & 0.4 & 2.9 & 8.7 & 15.5 & 19.8 \\
\hline 2119 & Project,2119,Window Technologies: Low-E Market Acceptance & 0.4 & 0.8 & 1.4 & 2.3 & 3.4 & 4.6 & 12.0 & 17.4 & 19.3 & 19.5 \\
\hline 145 & Analysis Tools and Design & 0.0 & 0.0 & 0.1 & 0.2 & 0.3 & 0.5 & 1.7 & 3.2 & 4.7 & 6.1 \\
\hline \multicolumn{12}{|c|}{ 7. Equipment Standards and Analysis } \\
\hline 603 & Equipment Standards and Analysis & \multicolumn{10}{|c|}{ Details in 6039-6044 } \\
\hline 6043 & Standards: Res. Gas Furnaces/Boilers & 0.0 & 0.0 & 0.0 & 0.0 & 0.1 & 0.1 & 0.5 & 1.0 & 1.4 & 2.0 \\
\hline
\end{tabular}




\begin{tabular}{|c|c|c|c|c|c|c|c|c|c|c|c|}
\hline \multirow{2}{*}{ Code } & \multirow{2}{*}{ Descriptor } & \multicolumn{10}{|c|}{ Effect on Total National Employment (Thousands of Jobs) } \\
\hline & & 2005 & 2006 & 2007 & 2008 & 2009 & 2010 & 2015 & 2020 & 2025 & 2030 \\
\hline 6044 & Standards: EPACT Standards & 0.4 & 0.5 & 0.7 & 1.7 & 2.9 & 4.1 & 11.3 & 19.0 & 22.0 & 25.2 \\
\hline 6039 & Standards: Distribution Transformers & 0.0 & 0.0 & 0.0 & 1.2 & 2.4 & 3.6 & 10.0 & 17.4 & 25.4 & 34.4 \\
\hline \multicolumn{2}{|c|}{ Building Technologies Program } & 2.2 & 3.3 & 5.9 & 11.5 & 18.0 & 25.5 & 79.0 & 161.9 & 297.4 & 419.8 \\
\hline
\end{tabular}


Table 2.3. Effect of Energy Savings from EERE Building Technologies Subprograms on Potential National Earned Income

\begin{tabular}{|c|c|c|c|c|c|c|c|c|c|c|c|}
\hline \multirow[t]{2}{*}{ Code } & \multirow[t]{2}{*}{ Descriptor } & \multicolumn{10}{|c|}{ Effect on Total National Earned Income (Million 2003\$) } \\
\hline & & 2005 & 2006 & 2007 & 2008 & 2009 & 2010 & 2015 & 2020 & 2025 & 2030 \\
\hline \multicolumn{12}{|c|}{ 1. Residential Buildings Integration } \\
\hline 115 & Res. Technology Research \& Development & $\$ 1.1$ & $\$ 2.2$ & $\$ 4.5$ & $\$ 8.1$ & $\$ 13.1$ & $\$ 20.0$ & $\$ 79.1$ & $\$ 171.5$ & $\begin{array}{r}\$ 295 . \\
0\end{array}$ & $\$ 445.7$ \\
\hline 506 & Residential Building Codes & 0.0 & 0.0 & 0.2 & 0.9 & 1.9 & 3.3 & 14.8 & 28.3 & 43.0 & 58.4 \\
\hline \multicolumn{12}{|c|}{ 2. Commercial Buildings Integration } \\
\hline 124 & Com. Technology Development & 0.4 & 1.1 & 2.4 & 4.5 & 7.6 & 15.0 & 69.4 & 103.9 & 109.8 & 109.5 \\
\hline 507 & Commercial Building Codes & 0.0 & 0.0 & 0.0 & 0.0 & 1.1 & 2.7 & 27.5 & 65.5 & 114.7 & 169.2 \\
\hline \multicolumn{12}{|c|}{ 3. Emerging Technologies } \\
\hline 430 & Lighting R\&D & & & & & & tails in 4 & $4-440$ & & & \\
\hline 4304 & Lighting R\&D: Controls & 3.8 & 5.0 & 7.6 & 11.2 & 15.5 & 20.4 & 49.5 & 74.5 & 96.9 & 120.9 \\
\hline 440 & Solid State Lighting & 0.0 & 0.0 & 0.0 & 0.0 & 0.0 & 0.1 & 27.8 & 309.6 & $\begin{array}{r}1,405 \\
.0\end{array}$ & $2,456.2$ \\
\hline 380 & Space Conditioning and Refrigeration R\&D & \multicolumn{10}{|c|}{ Details in $3801-3804$} \\
\hline 3801 & Refrigeration R\&D: Res. HVAC Dist. System & 0.0 & 0.0 & 0.0 & 0.2 & 0.5 & 1.1 & 9.6 & 31.7 & 55.1 & 69.3 \\
\hline 3802 & Refrigeration R\&D: Adv. Elec. HPWH & 0.2 & 0.5 & 1.1 & 2.1 & 3.6 & 5.9 & 35.3 & 87.0 & 97.8 & 53.4 \\
\hline 3803 & $\begin{array}{l}\text { Refrigeration R\&D: Commercial } \\
\text { Refrigeration }\end{array}$ & 1.3 & 1.9 & 3.0 & 4.8 & 7.2 & 10.4 & 36.7 & 45.7 & 21.7 & 4.3 \\
\hline 3804 & Refrigeration R\&D: Refrigerant Meter & 0.3 & 0.9 & 1.9 & 3.7 & 6.4 & 10.4 & 59.6 & 151.5 & 184.6 & 108.8 \\
\hline 381 & Appliances \& Emerging Technologies R\&D & \multicolumn{10}{|c|}{ Details in $3811-3817$} \\
\hline 3811 & Appliances \& Emerging Tech R\&D: HPWH & 4.1 & 5.0 & 7.9 & 12.0 & 17.2 & 26.1 & 64.8 & 80.4 & 98.0 & 118.1 \\
\hline 3813 & $\begin{array}{l}\text { Appliances \& Emerging Tech R\&D: Roof } \\
\text { Top AC }\end{array}$ & 1.0 & 1.4 & 1.9 & 2.4 & 2.6 & 3.0 & 4.2 & 5.1 & 6.0 & 7.1 \\
\hline 3816 & $\begin{array}{l}\text { Appliances \& Emerging Tech R\&D: } \\
\text { Recessed Can Lights }\end{array}$ & 0.3 & 0.8 & 1.8 & 3.3 & 5.1 & 7.1 & 11.2 & 11.5 & 11.5 & 11.6 \\
\hline 3817 & Appliances \& Emerging Tech R\&D: R-Lamp & 4.2 & 8.5 & 15.4 & 23.4 & 27.6 & 27.9 & 3.2 & 0.0 & 0.0 & 0.0 \\
\hline 2111 & $\begin{array}{l}\text { Building Envelope R\&D: Window } \\
\text { Technologies }\end{array}$ & \multicolumn{10}{|c|}{ Details in 2114-2119 } \\
\hline 2114 & $\begin{array}{l}\text { Window Technologies: Electrochromic } \\
\text { Windows }\end{array}$ & 0.0 & 0.0 & 0.0 & 0.0 & 0.0 & 0.5 & 16.6 & 80.3 & 208.6 & 353.9 \\
\hline 2115 & Window Technologies: Superwindows & 0.0 & 0.0 & 0.2 & 0.7 & 1.6 & 2.9 & 19.5 & 58.1 & 102.9 & 130.3 \\
\hline 2119 & $\begin{array}{l}\text { Window Technologies: Low-E Market } \\
\text { Acceptance }\end{array}$ & 2.9 & 5.7 & 10.9 & 17.7 & 25.6 & 34.2 & 86.9 & 122.2 & 130.7 & 128.0 \\
\hline 145 & Analysis Tools and Design & 0.2 & 0.6 & 1.4 & 2.6 & 4.3 & 6.6 & 22.5 & 40.9 & 59.3 & 76.3 \\
\hline
\end{tabular}


4. Equipment Standards and Analysis

603 Equipment Standards and Analysis

6043 Standards: Res. Gas Furnaces/Boilers

6044 Standards: EPACT Standards

6039 Standards: Distribution Transformers

5.

lding Technologies Program

$\$ 24.9$

$\$ 42.0$

$\begin{array}{rrr}0.0 & 0.0 & 0.0 \\ 8.4 & 12.4 & 31.8 \\ 0.0 & 0.0 & 22.2\end{array}$

Details in 6039-6044

$\begin{array}{lll}-0.9 & -1.9 & -6.8\end{array}$

$53.0 \quad 73.6 \quad 205.6$

$66.0 \quad 185.5$

$-12.2$

344.8

$-18.1$

398.8 
Table 2.4. Effect of the Full Investment Scenario on Potential National Employment

\begin{tabular}{|c|c|c|c|c|c|c|c|c|c|c|c|}
\hline \multirow{2}{*}{ Code } & \multirow{2}{*}{ Descriptor } & \multicolumn{10}{|c|}{ Effect on Total National Employment (Thousands of Jobs) } \\
\hline & & 2005 & 2006 & 2007 & 2008 & 2009 & 2010 & 2015 & 2020 & 2025 & 2030 \\
\hline \multicolumn{12}{|c|}{ 1. Residential Buildings Integration } \\
\hline 115 & Res. Technology Research \& Development & -0.1 & -0.2 & -0.2 & -0.2 & 0.0 & 0.4 & 6.5 & 17.8 & 32.0 & 49.4 \\
\hline 506 & Residential Building Codes & 0.0 & 0.0 & 0.0 & 0.1 & 0.2 & 0.3 & 1.9 & 4.1 & 6.4 & 8.8 \\
\hline \multicolumn{12}{|c|}{ 2. Commercial Buildings Integration } \\
\hline 124 & Com. Technology Development & -0.2 & -0.5 & -0.8 & -1.2 & -1.7 & -6.3 & -4.9 & 4.5 & 9.2 & 9.2 \\
\hline 507 & Commercial Building Codes & 0.0 & 0.0 & 0.0 & 0.0 & 0.0 & 0.1 & 1.4 & 3.6 & 6.5 & 9.7 \\
\hline \multicolumn{12}{|c|}{ 3. Emerging Technologies } \\
\hline 430 & Lighting R\&D & & & & & Details & $4304-$ & & & & \\
\hline 4304 & Lighting R\&D: Controls & 0.1 & 0.2 & 0.3 & 0.4 & 0.6 & 0.8 & 2.4 & 3.8 & 5.0 & 6.3 \\
\hline 440 & Solid State Lighting & 0.0 & 0.0 & 0.0 & 0.0 & 0.0 & 0.0 & 1.4 & 17.5 & 95.6 & 173.0 \\
\hline 380 & Space Conditioning and Refrigeration R\&D & \multicolumn{10}{|c|}{ Details in $3801-3804$} \\
\hline 3801 & Refrigeration R\&D: Res. HVAC Dist. System & 0.0 & 0.0 & 0.0 & 0.0 & 0.1 & 0.2 & 1.3 & 4.4 & 7.9 & 10.1 \\
\hline 3802 & Refrigeration R\&D: Adv. Elec. HPWH & 0.0 & 0.0 & 0.1 & 0.2 & 0.3 & 0.4 & 2.6 & 6.6 & 7.5 & 4.1 \\
\hline 3803 & Refrigeration R\&D: Commercial Refrigeration & 0.1 & 0.1 & 0.1 & 0.2 & 0.4 & 0.5 & 1.9 & 2.6 & 1.3 & 0.3 \\
\hline 3804 & Refrigeration R\&D: Refrigerant Meter & 0.0 & 0.0 & 0.1 & 0.2 & 0.4 & 0.7 & 4.1 & 10.9 & 13.7 & 8.2 \\
\hline 381 & Appliances \& Emerging Technologies R\&D & \multicolumn{10}{|c|}{ Details in 3811-3817 } \\
\hline 3811 & Appliances \& Emerging Tech R\&D: HPWH & 0.4 & 0.4 & 0.6 & 0.9 & 1.3 & 2.0 & 5.1 & 6.4 & 7.8 & 9.4 \\
\hline 3813 & Appliances \& Emerging Tech R\&D: Roof Top AC & 0.1 & 0.1 & 0.1 & 0.1 & 0.1 & 0.1 & 0.2 & 0.3 & 0.3 & 0.4 \\
\hline 3816 & Appliances \& Emerging Tech R\&D: Recessed Can Lights & 0.0 & 0.1 & 0.1 & 0.2 & 0.4 & 0.5 & 0.9 & 0.9 & 0.9 & 0.9 \\
\hline 3817 & Appliances \& Emerging Tech R\&D: R-Lamp & 0.4 & 0.7 & 1.2 & 1.9 & 2.2 & 2.2 & 0.3 & 0.0 & 0.0 & 0.0 \\
\hline 2111 & Building Envelope R\&D: Window Technologies & \multicolumn{10}{|c|}{ Details in 2114-2119 } \\
\hline 2114 & Window Technologies: Electrochromic Windows & 0.0 & 0.0 & 0.0 & 0.0 & 0.0 & -0.5 & -1.8 & 0.3 & 7.5 & 16.9 \\
\hline 2115 & Window Technologies: Superwindows & 0.0 & 0.0 & -0.2 & -0.4 & -0.7 & -1.0 & -2.0 & 1.0 & 9.5 & 17.4 \\
\hline 2119 & Window Technologies: Low-E Market Acceptance & 0.3 & 0.6 & 1.2 & 2.1 & 3.1 & 4.3 & 12.0 & 17.4 & 19.3 & 19.5 \\
\hline 145 & Analysis Tools and Design & 0.0 & -0.1 & -0.1 & -0.1 & -0.1 & 0.0 & 1.0 & 2.5 & 4.0 & 5.5 \\
\hline \multicolumn{12}{|c|}{ 4. Equipment Standards and Analysis } \\
\hline 603 & Equipment Standards and Analysis & \multicolumn{10}{|c|}{ Details in 6039-6044 } \\
\hline 6043 & Standards: Res. Gas Furnaces/Boilers & 0.0 & 0.0 & 0.0 & 0.0 & 0.0 & 0.1 & 0.5 & 1.0 & 1.4 & 2.0 \\
\hline 6044 & Standards: EPACT Standards & 0.1 & 0.2 & 0.5 & 0.6 & 1.7 & 2.9 & 9.8 & 17.3 & 21.4 & 24.5 \\
\hline
\end{tabular}




\begin{tabular}{|c|c|c|c|c|c|c|c|c|c|c|c|}
\hline \multirow{2}{*}{ Code } & \multirow{2}{*}{ Descriptor } & \multicolumn{10}{|c|}{ Effect on Total National Employment (Thousands of Jobs) } \\
\hline & & 2005 & 2006 & 2007 & 2008 & 2009 & 2010 & 2015 & 2020 & 2025 & 2030 \\
\hline 6039 & Standards: Distribution Transformers & 0.0 & 0.0 & 0.0 & -8.0 & -7.0 & -6.0 & -0.5 & 6.0 & 13.2 & 21.1 \\
\hline Building & echnologies Program & 1.0 & 1.5 & 2.9 & -3.1 & 1.3 & 1.7 & 44.2 & 128.7 & 270.3 & 396.4 \\
\hline
\end{tabular}


Table 2.5. Effect of the Full Investment Scenario on Potential National Earned Income

\begin{tabular}{|c|c|c|c|c|c|c|c|c|c|c|c|}
\hline \multirow{2}{*}{$\begin{array}{c}\text { Cod } \\
\text { e }\end{array}$} & \multirow{2}{*}{ Descriptor } & \multicolumn{10}{|c|}{ Effect on Total National Earned Income (Million 2003\$) } \\
\hline & & 2005 & 2006 & 2007 & 2008 & 2009 & 2010 & 2015 & 2020 & 2025 & 2030 \\
\hline \multicolumn{12}{|c|}{ 1. Residential Buildings Integration } \\
\hline 115 & Res. Technology Research \& Development & $\begin{array}{r}\$ 13 . \\
3\end{array}$ & $\$ 24$. & $\$ 38.3$ & $\$ 58.6$ & $\$ 80.2$ & $\begin{array}{r}\$ 106 . \\
0\end{array}$ & $\$ 198.0$ & $\$ 265.8$ & $\$ 394.2$ & $\$ 546.1$ \\
\hline 506 & Residential Building Codes & 0.0 & 0.0 & 0.9 & 3.4 & 5.5 & 8.5 & 25.1 & 40.3 & 55.5 & 71.3 \\
\hline \multicolumn{12}{|c|}{ 2. Commercial Buildings Integration } \\
\hline 124 & Com. Technology Development & 2.2 & 5.3 & 10.0 & 16.9 & 25.7 & 73.7 & 150.0 & 134.0 & 108.0 & 107.8 \\
\hline 507 & Commercial Building Codes & 0.0 & 0.0 & 0.0 & 0.1 & 3.1 & 6.1 & 40.8 & 83.6 & 137.4 & 193.9 \\
\hline \multicolumn{12}{|c|}{ 3. Emerging Technologies } \\
\hline 430 & Lighting R\&D & & & & & Deta & $\sin 430$ & & & & \\
\hline 4304 & Lighting R\&D: Controls & 1.9 & 3.8 & 6.0 & 8.9 & 12.8 & 17.3 & 46.0 & 71.5 & 94.0 & 117.8 \\
\hline 440 & Solid State Lighting & 0.0 & 0.0 & 0.0 & 0.0 & 0.0 & 0.4 & 30.9 & 311.6 & $1,403.1$ & $2,450.3$ \\
\hline 380 & Space Conditioning and Refrigeration R\&D & \multicolumn{10}{|c|}{ Details in 3801-3804 } \\
\hline 3801 & Refrigeration R\&D: Res. HVAC Dist. System & 0.0 & 0.0 & 0.0 & 0.9 & 1.5 & 2.4 & 13.8 & 38.1 & 56.3 & 63.7 \\
\hline 3802 & Refrigeration R\&D: Adv. Elec. HPWH & 0.3 & 0.8 & 1.8 & 3.2 & 5.4 & 8.6 & 47.7 & 101.9 & 106.1 & 54.9 \\
\hline 3803 & Refrigeration R\&D: Commercial Refrigeration & 2.2 & 2.6 & 4.1 & 6.4 & 9.4 & 13.4 & 41.5 & 44.6 & 16.4 & 2.5 \\
\hline 3804 & Refrigeration R\&D: Refrigerant Meter & 0.5 & 1.2 & 2.6 & 4.9 & 8.2 & 13.1 & 69.7 & 167.0 & 192.4 & 110.4 \\
\hline 381 & Appliances \& Emerging Technologies R\&D & \multicolumn{10}{|c|}{ Details in 3811-3817 } \\
\hline 3811 & Appliances \& Emerging Tech R\&D: HPWH & 5.2 & 6.8 & 10.5 & 15.5 & 21.5 & 33.1 & 69.4 & 85.1 & 102.9 & 123.1 \\
\hline 3813 & Appliances \& Emerging Tech R\&D: Roof Top AC & 1.5 & 1.8 & 2.3 & 2.7 & 3.0 & 3.3 & 4.5 & 5.4 & 6.3 & 7.3 \\
\hline 3816 & $\begin{array}{l}\text { Appliances \& Emerging Tech R\&D: Recessed Can } \\
\text { Lights }\end{array}$ & 0.4 & 1.0 & 2.1 & 3.7 & 5.6 & 7.5 & 11.3 & 11.5 & 11.5 & 11.6 \\
\hline 3817 & Appliances \& Emerging Tech R\&D: R-Lamp & 4.2 & 8.6 & 15.5 & 23.5 & 27.7 & 27.9 & 3.2 & 0.0 & 0.0 & 0.0 \\
\hline 2111 & Building Envelope R\&D: Window Technologies & \multicolumn{10}{|c|}{ Details in 2114-2119 } \\
\hline 2114 & Window Technologies: Electrochromic Windows & 0.0 & 0.0 & 0.0 & 0.0 & 0.0 & 14.8 & 89.0 & 195.1 & 326.2 & 443.8 \\
\hline 2115 & Window Technologies: Superwindows & 0.0 & 0.0 & 2.5 & 5.6 & 9.7 & 16.0 & 64.3 & 128.2 & 157.6 & 151.7 \\
\hline 2119 & Window Technologies: Low-E Market Acceptance & 6.4 & 12.1 & 19.5 & 28.2 & 37.2 & 45.1 & 86.9 & 122.2 & 130.7 & 128.0 \\
\hline 145 & Analysis Tools and Design & 2.7 & 5.9 & 9.9 & 15.1 & 21.2 & 27.2 & 53.9 & 71.7 & 88.0 & 103.9 \\
\hline \multicolumn{12}{|c|}{ 4. Equipment Standards and Analysis } \\
\hline 603 & Equipment Standards and Analysis & \multicolumn{10}{|c|}{ Details in 6039-6044 } \\
\hline 6043 & Standards: Res. Gas Furnaces/Boilers & 0.0 & 0.0 & 0.0 & 0.0 & -0.4 & -1.3 & -6.6 & -12.1 & -18.0 & -24.7 \\
\hline
\end{tabular}




\begin{tabular}{|c|c|c|c|c|c|c|c|c|c|c|c|}
\hline \multirow{2}{*}{$\begin{array}{c}\text { Cod } \\
\text { e }\end{array}$} & \multirow{2}{*}{ Descriptor } & \multicolumn{10}{|c|}{ Effect on Total National Earned Income (Million 2003\$) } \\
\hline & & 2005 & 2006 & 2007 & 2008 & 2009 & 2010 & 2015 & 2020 & 2025 & 2030 \\
\hline 6044 & Standards: EPACT Standards & 15.6 & 19.3 & 22.4 & 83.1 & 109.4 & 128.4 & 276.1 & 420.2 & 429.3 & 487.2 \\
\hline 6039 & Standards: Distribution Transformers & 0.0 & 0.0 & 0.0 & -87.2 & -67.2 & -47.8 & 61.2 & 187.3 & 325.3 & 479.0 \\
\hline \multicolumn{2}{|c|}{ Building Technologies Program } & $\begin{array}{r}\$ 56 . \\
5 \\
\end{array}$ & $\begin{array}{r}\$ 93 . \\
6 \\
\end{array}$ & $\begin{array}{r}\$ 148 . \\
5\end{array}$ & $\begin{array}{r}\$ 193 . \\
5\end{array}$ & $\begin{array}{r}\$ 319 . \\
7\end{array}$ & $\begin{array}{r}\$ 503 . \\
8 \\
\end{array}$ & $\begin{array}{r}\$ 1,376 \text {. } \\
8\end{array}$ & $\begin{array}{r}\$ 2,473 \text {. } \\
\end{array}$ & $\begin{array}{r}\$ 4,123 . \\
3\end{array}$ & $\begin{array}{r}\$ 5,629 . \\
7\end{array}$ \\
\hline
\end{tabular}




\subsection{Summary of Impacts}

The improvements in energy efficiency expected from EERE's Building Technologies Program require a significant annual capital expense of just under $\$ 1$ billion to over $\$ 16$ billion per year to achieve, as shown in Table 2.1. (The peak investment year is actually 2015, with an investment expenditure of about $\$ 18$ billion.) Initially, this annual investment is larger than the annual savings. However, because the stock of energy efficient equipment and practices continues to grow, the annual savings eventually outstrip the investment. By 2030 the energy savings alone, as shown in Table 2.1, are $\$ 61$ billion per year, a significant national benefit. This does not count other obvious benefits, such as operational savings due to improved durability and efficiency of equipment, improved environmental quality from reduced burning of fossil fuels, and improved livability and increased value of structures. The impacts presented in Tables 2.2 through 2.5 illustrate the growing importance of energy efficiency through time to the U.S. economy as a result of these savings. By the year 2015, the net positive impacts are about 44,000 jobs and $\$ 1.4$ billion in earnings, but by 2030 the impacts grow to around 396,000 jobs and over $\$ 5.6$ billion, between four and nine times larger. 


\subsection{References}

Bureau of Economic Analysis. 1992. Regional Multipliers: A User Handbook for the Regional InputOutput Modeling System (RIMS II). Washington D.C.: U.S. Department of Commerce.

Elliott, D.B., D.M. Anderson, D.B. Belzer, K.A. Cort, J.A. Dirks, and D.J. Hostick. 2004.

Methodological Framework for Analysis of Buildings-Related Programs: GPRA Metrics Effort. PNNL14697. Pacific Northwest National Laboratory, Richland, Washington.

Energy Information Administration (EIA). 2002. Assumptions to the Annual Energy Outlook 2002. DOE/EIA-0554(2002). Energy Information Administration, U.S. Department of Energy, Washington, D.C.

Energy Information Administration (EIA). 1996. Natural Gas 1996: Issues and Trends. DOE/EIA-0560(96). Energy Information Administration, U.S. Department of Energy, Washington, D.C.

Energy Information Administration (EIA). 1999. Natural Gas 1998: Issues and Trends.

DOE/EIA-0560(98). Energy Information Administration, U.S. Department of Energy, Washington, D.C.

Minnesota IMPLAN Group, Inc. 1997. IMPLAN Professional: Social Accounting and Impact Analysis Software. Minnesota IMPLAN Group, Inc., Stillwater, Minnesota.

Scott, M.J., J.M Roop, and R.W. Schultz. 2002. ImBuild II: Impact of Building Energy Efficiency Programs. PNNL-13926. Pacific Northwest National Laboratory, Richland, Washington. 


\section{Attachment: Detailed Calculations on EERE Building Technologies Subprograms}




\section{Attachment: Detailed Calculations on EERE Building Technologies Subprograms}

\section{Table Notes}

Table A.1: This table shows the effects of individual EERE Building Technologies subprograms (identified by their 2005 GPRA codes and titles) on national incremental investment in energy-efficient technology or practices in individual years. Current investment spending is reported each year because current investment spending affects current employment and earned income. Also shown for each year and subprogram are the effects of the accumulated investments on current expenditures for oil, natural gas, and electricity. (Impacts on non-energy expenditures for items such as maintenance services generally have not been estimated and are not shown.) Current spending affects current employment and earned income. In most cases, the investment is expected to reduce net fuel expenditure, but sometimes consumption of one fuel will be altered by the change in consumption of another, resulting in an increased expenditure for that fuel. Thus, for example, for Subprogram Code 3816, Appliances and Emerging Tech R\&D: Recessed Can Lights, Table A.1 shows the nation spending \$123 million less for electricity for the residential sector, but spending slightly more for residential natural gas in the year 2030 than it otherwise would have. This happens because adopting more efficient electric equipment results in less unintentional heating of conditioned space in the winter from lighting, requiring that slightly more natural gas be burned. Similarly, Subprogram 2114, Electrochromic Windows, shows significant electricity savings in commercial buildings for cooling, but some additional oil is required in northern locations to provide heating during the winter because of the lower requirement for lighting.

Table A.2: Purchases from different industrial sectors of the economy are associated with different interindustry sales of goods and services and different requirements for labor (e.g., an increase in purchases of plastic-framed efficient windows will not have an identical impact to increased purchases of more efficient refrigerators; because the production processes and materials used are different). Therefore, to estimate the impact of a given investment, the investment must be allocated to the sectors from which the investing business or household buys equipment and services. This table shows how the incremental investment premium associated with each EERE Building Technologies Program subprogram is assumed to be distributed among industrial sectors. The assumed allocation in each case was made in consultation with the GPRA researchers, based on subprogram information provided by DOE subprogram managers, as well as the characteristics of the technologies that are expected to be adopted as a result of the subprogram. For example, Subprogram 440, Solid State Lighting, is expected to result in incremental investments, divided one-half each to the two manufacturing sectors that will produce the equipment: Lighting Bulbs and Tubes and Other Lighting and Wiring. These units are expected to be more expensive to manufacture than are equivalent units using conventional technology. Because no incremental installation cost or retail markup is expected, the entire premium results from the fact that these units are expected to be more expensive to manufacture than those with the conventional technology. 
Table A.1. EERE Building Technologies Subprogram Investment Costs and Energy Savings, by Year (Million \$2003)

\begin{tabular}{|c|c|c|c|c|}
\hline \multirow{2}{*}{ Subprogram and Category } & \multicolumn{4}{|c|}{ Fiscal Year } \\
\hline & 2005 & 2010 & 2020 & 2030 \\
\hline \multicolumn{5}{|l|}{ 1. Residential Buildings } \\
\hline 115 & \multicolumn{4}{|c|}{ Research \& Development (Building America) } \\
\hline Investment & $\$ 219.9$ & $\$ 1,551.2$ & $\$ 1,699.8$ & $\$ 1,812.9$ \\
\hline Expenditures on Oil, Residential & $-\$ 1.2$ & $-\$ 30.6$ & $-\$ 274.2$ & $-\$ 743.6$ \\
\hline Expenditures on Oil, Commercial & $\$ 0.0$ & $\$ 0.0$ & $\$ 0.0$ & $\$ 0.0$ \\
\hline Expenditures on Natural Gas, Residential & $-\$ 3.7$ & $-\$ 92.0$ & $-\$ 776.6$ & $-\$ 1,985.8$ \\
\hline Expenditures on Natural Gas, Commercial & $\$ 0.0$ & $\$ 0.0$ & $\$ 0.0$ & $\$ 0.0$ \\
\hline Expenditures on Electricity, Residential & $-\$ 9.4$ & $-\$ 245.4$ & $-\$ 2,094.8$ & $-\$ 5,411.5$ \\
\hline Expenditures on Electricity, Commercial & $\$ 0.0$ & $\$ 0.0$ & $\$ 0.0$ & $\$ 0.0$ \\
\hline Change in Energy Expenditures & $-\$ 14.3$ & $-\$ 368.0$ & $-\$ 3,145.6$ & $-\$ 8,140.9$ \\
\hline 506 & \multicolumn{4}{|c|}{ Residential Building Energy Codes } \\
\hline Investment & $\$ 0.0$ & $\$ 121.8$ & $\$ 284.5$ & $\$ 304.4$ \\
\hline Expenditures on Oil, Residential & $\$ 0.0$ & $-\$ 5.8$ & $-\$ 65.0$ & $-\$ 140.5$ \\
\hline Expenditures on Oil, Commercial & $\$ 0.0$ & $\$ 0.0$ & $\$ 0.0$ & $\$ 0.0$ \\
\hline Expenditures on Natural Gas, Residential & $\$ 0.0$ & $-\$ 26.8$ & $-\$ 277.6$ & $-\$ 584.7$ \\
\hline Expenditures on Natural Gas, Commercial & $\$ 0.0$ & $\$ 0.0$ & $\$ 0.0$ & $\$ 0.0$ \\
\hline Expenditures on Electricity, Residential & $\$ 0.0$ & $-\$ 45.9$ & $-\$ 406.4$ & $-\$ 843.1$ \\
\hline Expenditures on Electricity, Commercial & $\$ 0.0$ & $\$ 0.0$ & $\$ 0.0$ & $\$ 0.0$ \\
\hline Change in Energy Expenditures & $\$ 0.0$ & $-\$ 78.5$ & $-\$ 749.0$ & $-\$ 1,568.2$ \\
\hline \multicolumn{5}{|l|}{ 2. Commercial Buildings Integration } \\
\hline 124 & \multicolumn{4}{|c|}{ Research \& Development } \\
\hline Investment & $\$ 123.0$ & $\$ 4,054.1$ & $\$ 2,076.8$ & $-\$ 118.8$ \\
\hline Expenditures on Oil, Residential & $\$ 0.0$ & $-\$ 0.2$ & $-\$ 1.3$ & $\$ 0.1$ \\
\hline Expenditures on Oil, Commercial & $-\$ 0.1$ & $-\$ 3.8$ & $-\$ 23.7$ & $-\$ 25.8$ \\
\hline Expenditures on Natural Gas, Residential & $-\$ 0.1$ & $-\$ 4.9$ & $-\$ 38.5$ & $-\$ 36.1$ \\
\hline Expenditures on Natural Gas, Commercial & $-\$ 1.4$ & $-\$ 68.3$ & $-\$ 558.8$ & $-\$ 692.6$ \\
\hline Expenditures on Electricity, Residential & $-\$ 0.4$ & $-\$ 31.3$ & $-\$ 241.9$ & $-\$ 207.5$ \\
\hline Expenditures on Electricity, Commercial & $-\$ 1.9$ & $-\$ 84.4$ & $-\$ 569.6$ & $-\$ 627.6$ \\
\hline Change in Energy Expenditures & $-\$ 3.8$ & $-\$ 192.9$ & $-\$ 1,433.7$ & $-\$ 1,589.5$ \\
\hline 507 & \multicolumn{4}{|c|}{ Commercial Building Energy Codes } \\
\hline Investment & $\$ 0.0$ & $\$ 49.1$ & $\$ 260.9$ & $\$ 353.3$ \\
\hline Expenditures on Oil, Residential & $\$ 0.0$ & $\$ 0.0$ & $\$ 0.0$ & $\$ 0.0$ \\
\hline Expenditures on Oil, Commercial & $\$ 0.0$ & $\$ 0.0$ & $\$ 0.0$ & $\$ 0.0$ \\
\hline Expenditures on Natural Gas, Residential & $\$ 0.0$ & $\$ 0.0$ & $\$ 0.0$ & $\$ 0.0$ \\
\hline Expenditures on Natural Gas, Commercial & $\$ 0.0$ & $-\$ 2.6$ & $-\$ 85.2$ & $-\$ 242.8$ \\
\hline Expenditures on Electricity, Residential & $\$ 0.0$ & $\$ 0.0$ & $\$ 0.0$ & $\$ 0.0$ \\
\hline Expenditures on Electricity, Commercial & $\$ 0.0$ & $-\$ 19.5$ & $-\$ 468.3$ & $-\$ 1,210.5$ \\
\hline Change in Energy Expenditures & $\$ 0.0$ & $-\$ 22.1$ & $-\$ 553.5$ & $-\$ 1,453.3$ \\
\hline \multicolumn{5}{|l|}{ 3. Emerging Technologies } \\
\hline 430 & \multicolumn{4}{|c|}{ Lighting R\&D } \\
\hline 4304 & \multicolumn{4}{|c|}{ Lighting R\&D: Controls } \\
\hline Investment & $\$ 63.1$ & $\$ 102.0$ & $\$ 97.7$ & $\$ 98.9$ \\
\hline Expenditures on Oil, Residential & $\$ 0.0$ & $\$ 0.0$ & $\$ 0.0$ & $\$ 0.0$ \\
\hline Expenditures on Oil, Commercial & $\$ 0.0$ & $\$ 0.0$ & $\$ 0.0$ & $\$ 0.0$ \\
\hline Expenditures on Natural Gas, Residential & $\$ 0.0$ & $\$ 0.0$ & $\$ 0.0$ & $\$ 0.0$ \\
\hline
\end{tabular}




\begin{tabular}{|c|c|c|c|c|}
\hline \multirow{2}{*}{ Subprogram and Category } & \multicolumn{4}{|c|}{ Fiscal Year } \\
\hline & 2005 & 2010 & 2020 & 2030 \\
\hline Expenditures on Natural Gas, Commercial & $\$ 0.0$ & $\$ 0.0$ & $\$ 0.0$ & $\$ 0.0$ \\
\hline Expenditures on Electricity, Residential & $\$ 0.0$ & $\$ 0.0$ & $\$ 0.0$ & $\$ 0.0$ \\
\hline Expenditures on Electricity, Commercial & $-\$ 21.8$ & $-\$ 146.5$ & $-\$ 535.1$ & $-\$ 868.4$ \\
\hline Change in Energy Expenditures & $-\$ 21.8$ & $-\$ 146.5$ & $-\$ 535.1$ & $-\$ 868.4$ \\
\hline 440 & \multicolumn{4}{|c|}{ Solid State Lighting } \\
\hline Investment & $\$ 0.0$ & $\$ 4.7$ & $\$ 43.5$ & $-\$ 124.9$ \\
\hline Expenditures on Oil, Residential & $\$ 0.0$ & $\$ 0.0$ & $\$ 0.0$ & $\$ 0.0$ \\
\hline Expenditures on Oil, Commercial & $\$ 0.0$ & $\$ 0.0$ & $\$ 0.0$ & $\$ 0.0$ \\
\hline Expenditures on Natural Gas, Residential & $\$ 0.0$ & $\$ 0.0$ & $\$ 0.0$ & $\$ 0.0$ \\
\hline Expenditures on Natural Gas, Commercial & $\$ 0.0$ & $\$ 0.0$ & $\$ 0.0$ & $\$ 0.0$ \\
\hline Expenditures on Electricity, Residential & $\$ 0.0$ & $\$ 0.0$ & $-\$ 329.5$ & $-\$ 16,232.7$ \\
\hline Expenditures on Electricity, Commercial & $\$ 0.0$ & $-\$ 1.0$ & $-\$ 2,004.5$ & $-\$ 6,792.6$ \\
\hline Change in Energy Expenditures & $\$ 0.0$ & $-\$ 1.0$ & $-\$ 2,334.0$ & $-\$ 23,025.3$ \\
\hline 380 & \multicolumn{4}{|c|}{ Space Conditioning \& Refrigeration R\&D } \\
\hline 3801 & \multicolumn{4}{|c|}{ Refrigeration R\&D: Res. HVAC Dist. System } \\
\hline Investment & $\$ 0.0$ & $\$ 15.5$ & $\$ 76.8$ & $-\$ 67.1$ \\
\hline Expenditures on Oil, Residential & $\$ 0.0$ & $-\$ 0.6$ & $-\$ 9.8$ & $-\$ 18.9$ \\
\hline Expenditures on Oil, Commercial & $\$ 0.0$ & $\$ 0.0$ & $\$ 0.0$ & $\$ 0.0$ \\
\hline Expenditures on Natural Gas, Residential & $\$ 0.0$ & $-\$ 8.5$ & $-\$ 255.2$ & $-\$ 647.2$ \\
\hline Expenditures on Natural Gas, Commercial & $\$ 0.0$ & $\$ 0.0$ & $\$ 0.0$ & $\$ 0.0$ \\
\hline Expenditures on Electricity, Residential & $\$ 0.0$ & $-\$ 15.7$ & $-\$ 454.3$ & $-\$ 1,035.9$ \\
\hline Expenditures on Electricity, Commercial & $\$ 0.0$ & $\$ 0.0$ & $\$ 0.0$ & $\$ 0.0$ \\
\hline Change in Energy Expenditures & $\$ 0.0$ & $-\$ 24.7$ & $-\$ 719.3$ & $-\$ 1,702.0$ \\
\hline 3802 & \multicolumn{4}{|c|}{ Refrigeration R\&D: Adv. Elec. HPWH } \\
\hline Investment & $\$ 3.1$ & $\$ 54.3$ & $\$ 296.7$ & $\$ 29.9$ \\
\hline Expenditures on Oil, Residential & $\$ 0.0$ & $\$ 0.0$ & $\$ 0.0$ & $\$ 0.0$ \\
\hline Expenditures on Oil, Commercial & $\$ 0.0$ & $\$ 0.0$ & $\$ 0.0$ & $\$ 0.0$ \\
\hline Expenditures on Natural Gas, Residential & $\$ 0.0$ & $\$ 0.0$ & $\$ 0.0$ & $\$ 0.0$ \\
\hline Expenditures on Natural Gas, Commercial & $\$ 0.0$ & $\$ 0.0$ & $\$ 0.0$ & $\$ 0.0$ \\
\hline Expenditures on Electricity, Residential & $-\$ 1.2$ & $-\$ 54.8$ & $-\$ 821.6$ & $-\$ 507.3$ \\
\hline Expenditures on Electricity, Commercial & $-\$ 0.2$ & $-\$ 5.5$ & $-\$ 76.5$ & $-\$ 44.6$ \\
\hline Change in Energy Expenditures & $-\$ 1.4$ & $-\$ 60.3$ & $-\$ 898.0$ & $-\$ 551.9$ \\
\hline 3803 & \multicolumn{4}{|c|}{ Refrigeration R\&D: Commercial Refrigeration } \\
\hline Investment & $\$ 18.0$ & $\$ 58.0$ & $-\$ 22.5$ & $-\$ 33.8$ \\
\hline Expenditures on Oil, Residential & $\$ 0.0$ & $\$ 0.0$ & $\$ 0.0$ & $\$ 0.0$ \\
\hline Expenditures on Oil, Commercial & $\$ 0.0$ & $\$ 0.0$ & $\$ 0.0$ & $\$ 0.0$ \\
\hline Expenditures on Natural Gas, Residential & $\$ 0.0$ & $\$ 0.0$ & $\$ 0.0$ & $\$ 0.0$ \\
\hline Expenditures on Natural Gas, Commercial & $-\$ 0.4$ & $-\$ 4.7$ & $-\$ 20.8$ & $-\$ 2.0$ \\
\hline Expenditures on Electricity, Residential & $\$ 0.0$ & $\$ 0.0$ & $\$ 0.0$ & $\$ 0.0$ \\
\hline Expenditures on Electricity, Commercial & $-\$ 7.6$ & $-\$ 78.8$ & $-\$ 346.0$ & $-\$ 32.3$ \\
\hline Change in Energy Expenditures & $-\$ 8.0$ & $-\$ 83.5$ & $-\$ 366.8$ & $-\$ 34.3$ \\
\hline 3804 & \multicolumn{4}{|c|}{ Refrigeration R\&D: Refrigerant Meter } \\
\hline Investment & $\$ 4.3$ & $\$ 73.7$ & $\$ 413.8$ & $\$ 44.4$ \\
\hline Expenditures on Oil, Residential & $\$ 0.0$ & $\$ 0.0$ & $\$ 0.0$ & $\$ 0.0$ \\
\hline Expenditures on Oil, Commercial & $\$ 0.0$ & $\$ 0.0$ & $\$ 0.0$ & $\$ 0.0$ \\
\hline Expenditures on Natural Gas, Residential & $\$ 0.0$ & $\$ 0.0$ & $\$ 0.0$ & $\$ 0.0$ \\
\hline Expenditures on Natural Gas, Commercial & $\$ 0.0$ & $\$ 0.0$ & $\$ 0.0$ & $\$ 0.0$ \\
\hline Expenditures on Electricity, Residential & $-\$ 2.0$ & $-\$ 88.5$ & $-\$ 1,323.6$ & $-\$ 965.1$ \\
\hline Expenditures on Electricity, Commercial & $-\$ 0.5$ & $-\$ 15.3$ & $-\$ 204.1$ & $-\$ 136.5$ \\
\hline Change in Energy Expenditures & $-\$ 2.5$ & $-\$ 103.8$ & $-\$ 1,527.7$ & $-\$ 1,101.7$ \\
\hline
\end{tabular}




\begin{tabular}{|c|c|c|c|c|}
\hline \multirow{2}{*}{ Subprogram and Category } & \multicolumn{4}{|c|}{ Fiscal Year } \\
\hline & 2005 & 2010 & 2020 & 2030 \\
\hline 381 & \multicolumn{4}{|c|}{ Appliances \& Emerging Technologies R\&D } \\
\hline 3811 & \multicolumn{4}{|c|}{ Appliances \& Emerging Tech R\&D: HPWH } \\
\hline Investment & $\$ 23.2$ & $\$ 139.9$ & $\$ 95.4$ & $\$ 101.3$ \\
\hline Expenditures on Oil, Residential & $\$ 0.0$ & $\$ 0.0$ & $\$ 0.0$ & $\$ 0.0$ \\
\hline Expenditures on Oil, Commercial & $\$ 0.0$ & $\$ 0.0$ & $\$ 0.0$ & $\$ 0.0$ \\
\hline Expenditures on Natural Gas, Residential & $\$ 0.0$ & $\$ 0.0$ & $\$ 0.0$ & $\$ 0.0$ \\
\hline Expenditures on Natural Gas, Commercial & $\$ 0.0$ & $\$ 0.0$ & $\$ 0.0$ & $\$ 0.0$ \\
\hline Expenditures on Electricity, Residential & $-\$ 33.0$ & $-\$ 281.1$ & $-\$ 864.3$ & $-\$ 1,269.5$ \\
\hline Expenditures on Electricity, Commercial & $\$ 0.0$ & $\$ 0.0$ & $\$ 0.0$ & $\$ 0.0$ \\
\hline Change in Energy Expenditures & $-\$ 33.0$ & $-\$ 281.1$ & $-\$ 864.3$ & $-\$ 1,269.5$ \\
\hline 3813 & \multicolumn{4}{|c|}{ Appliances \& Emerging Tech R\&D: Roof Top AC } \\
\hline Investment & $\$ 13.8$ & $\$ 8.7$ & $\$ 8.5$ & $\$ 7.7$ \\
\hline Expenditures on Oil, Residential & $\$ 0.0$ & $\$ 0.0$ & $\$ 0.0$ & $\$ 0.0$ \\
\hline Expenditures on Oil, Commercial & $\$ 0.0$ & $\$ 0.0$ & $\$ 0.0$ & $\$ 0.0$ \\
\hline Expenditures on Natural Gas, Residential & $\$ 0.0$ & $\$ 0.0$ & $\$ 0.0$ & $\$ 0.0$ \\
\hline Expenditures on Natural Gas, Commercial & $\$ 0.0$ & $\$ 0.0$ & $\$ 0.0$ & $\$ 0.0$ \\
\hline Expenditures on Electricity, Residential & $\$ 0.0$ & $\$ 0.0$ & $\$ 0.0$ & $\$ 0.0$ \\
\hline Expenditures on Electricity, Commercial & $-\$ 5.7$ & $-\$ 21.4$ & $-\$ 36.6$ & $-\$ 50.7$ \\
\hline Change in Energy Expenditures & $-\$ 5.7$ & $-\$ 21.4$ & $-\$ 36.6$ & $-\$ 50.7$ \\
\hline 3816 & \multicolumn{4}{|c|}{$\begin{array}{l}\text { Appliances \& Emerging Tech R\&D: Recessed Can } \\
\text { Lights }\end{array}$} \\
\hline Investment & $\$ 1.4$ & $\$ 9.1$ & $\$ 0.0$ & $\$ 0.0$ \\
\hline Expenditures on Oil, Residential & $\$ 0.0$ & $\$ 0.0$ & $\$ 0.0$ & $\$ 0.0$ \\
\hline Expenditures on Oil, Commercial & $\$ 0.0$ & $\$ 0.0$ & $\$ 0.0$ & $\$ 0.0$ \\
\hline Expenditures on Natural Gas, Residential & $\$ 0.1$ & $\$ 2.6$ & $\$ 4.1$ & $\$ 4.1$ \\
\hline Expenditures on Natural Gas, Commercial & $\$ 0.0$ & $\$ 0.0$ & $\$ 0.0$ & $\$ 0.0$ \\
\hline Expenditures on Electricity, Residential & $-\$ 2.4$ & $-\$ 75.1$ & $-\$ 121.4$ & $-\$ 123.1$ \\
\hline Expenditures on Electricity, Commercial & $\$ 0.0$ & $\$ 0.0$ & $\$ 0.0$ & $\$ 0.0$ \\
\hline Change in Energy Expenditures & $-\$ 2.3$ & $-\$ 72.5$ & $-\$ 117.2$ & $-\$ 118.9$ \\
\hline 3817 & \multicolumn{4}{|c|}{ Appliances \& Emerging Tech R\&D: R-Lamp } \\
\hline Investment & $\$ 0.8$ & $\$ 1.0$ & $\$ 0.0$ & $\$ 0.0$ \\
\hline Expenditures on Oil, Residential & $\$ 0.1$ & $\$ 0.5$ & $\$ 0.0$ & $\$ 0.0$ \\
\hline Expenditures on Oil, Commercial & $\$ 0.0$ & $\$ 0.0$ & $\$ 0.0$ & $\$ 0.0$ \\
\hline Expenditures on Natural Gas, Residential & $\$ 0.6$ & $\$ 5.9$ & $\$ 0.0$ & $\$ 0.0$ \\
\hline Expenditures on Natural Gas, Commercial & $\$ 0.0$ & $\$ 0.0$ & $\$ 0.0$ & $\$ 0.0$ \\
\hline Expenditures on Electricity, Residential & $-\$ 33.4$ & $-\$ 297.6$ & $-\$ 0.4$ & $\$ 0.0$ \\
\hline Expenditures on Electricity, Commercial & $\$ 0.0$ & $\$ 0.0$ & $\$ 0.0$ & $\$ 0.0$ \\
\hline Change in Energy Expenditures & $-\$ 32.7$ & $-\$ 291.2$ & $-\$ 0.4$ & $\$ 0.0$ \\
\hline 2111 & \multicolumn{4}{|c|}{ Building Envelope R\&D: Window Technologies } \\
\hline 2114 & \multicolumn{4}{|c|}{ Window Technologies: Electrochromic Windows } \\
\hline Investment & $\$ 0.0$ & $\$ 291.1$ & $\$ 2,337.2$ & $\$ 1,828.2$ \\
\hline Expenditures on Oil, Residential & $\$ 0.0$ & $\$ 0.0$ & $\$ 0.0$ & $\$ 0.0$ \\
\hline Expenditures on Oil, Commercial & $\$ 0.0$ & $\$ 0.0$ & $\$ 0.8$ & $\$ 5.0$ \\
\hline Expenditures on Natural Gas, Residential & $\$ 0.0$ & $\$ 0.0$ & $\$ 0.0$ & $\$ 0.0$ \\
\hline Expenditures on Natural Gas, Commercial & $\$ 0.0$ & $-\$ 0.4$ & $-\$ 75.4$ & $-\$ 343.9$ \\
\hline Expenditures on Electricity, Residential & $\$ 0.0$ & $\$ 0.0$ & $\$ 0.0$ & $\$ 0.0$ \\
\hline Expenditures on Electricity, Commercial & $\$ 0.0$ & $-\$ 3.6$ & $-\$ 575.6$ & $-\$ 2,538.8$ \\
\hline Change in Energy Expenditures & $\$ 0.0$ & $-\$ 4.0$ & $-\$ 650.2$ & $-\$ 2,877.7$ \\
\hline
\end{tabular}




\begin{tabular}{|c|c|c|c|c|}
\hline 2115 & \multicolumn{3}{|c|}{ Window Technologies: Superwindows } & \multirow[b]{2}{*}{$\$ 772.7$} \\
\hline Investment & $\$ 0.0$ & $\$ 471.3$ & $\$ 2,518.4$ & \\
\hline Expenditures on Oil, Residential & $\$ 0.0$ & $-\$ 2.9$ & $-\$ 50.1$ & $-\$ 119.7$ \\
\hline Expenditures on Oil, Commercial & $\$ 0.0$ & $\$ 0.0$ & $\$ 0.0$ & $\$ 0.0$ \\
\hline Expenditures on Natural Gas, Residential & $\$ 0.0$ & $-\$ 25.8$ & $-\$ 564.0$ & $-\$ 1,294.0$ \\
\hline Expenditures on Natural Gas, Commercial & $\$ 0.0$ & $\$ 0.0$ & $\$ 0.0$ & $\$ 0.0$ \\
\hline Expenditures on Electricity, Residential & $\$ 0.0$ & $-\$ 42.1$ & $-\$ 865.5$ & $-\$ 1,950.2$ \\
\hline Expenditures on Electricity, Commercial & $\$ 0.0$ & $\$ 0.0$ & $\$ 0.0$ & $\$ 0.0$ \\
\hline Change in Energy Expenditures & $\$ 0.0$ & $-\$ 70.8$ & $-\$ 1,479.6$ & $-\$ 3,363.9$ \\
\hline 2119 & \multicolumn{4}{|c|}{ Window Technologies: Low-E Market Acceptance } \\
\hline Investment & $\$ 66.8$ & $\$ 203.7$ & $\$ 0.0$ & $\$ 0.0$ \\
\hline Expenditures on Oil, Residential & $-\$ 2.0$ & $-\$ 24.7$ & $-\$ 74.5$ & $-\$ 86.3$ \\
\hline Expenditures on Oil, Commercial & $-\$ 0.1$ & $-\$ 2.8$ & $-\$ 40.4$ & $-\$ 64.6$ \\
\hline Expenditures on Natural Gas, Residential & $-\$ 12.8$ & $-\$ 253.1$ & $-\$ 958.6$ & $-\$ 1,089.9$ \\
\hline Expenditures on Natural Gas, Commercial & $-\$ 0.4$ & $-\$ 16.0$ & $-\$ 248.6$ & $-\$ 379.4$ \\
\hline Expenditures on Electricity, Residential & $-\$ 24.9$ & $-\$ 466.1$ & $-\$ 1,654.1$ & $-\$ 1,844.0$ \\
\hline Expenditures on Electricity, Commercial & $-\$ 0.2$ & $-\$ 4.1$ & $-\$ 19.0$ & $\$ 46.6$ \\
\hline Change in Energy Expenditures & $-\$ 40.5$ & $-\$ 766.6$ & $-\$ 2,995.1$ & $-\$ 3,417.5$ \\
\hline 145 & \multicolumn{4}{|c|}{ Analysis Tools and Design } \\
\hline Investment & $\$ 63.1$ & $\$ 523.3$ & $\$ 782.4$ & $\$ 699.9$ \\
\hline Expenditures on Oil, Residential & $\$ 0.0$ & $\$ 0.0$ & $\$ 0.0$ & $\$ 0.0$ \\
\hline Expenditures on Oil, Commercial & $\$ 0.0$ & $-\$ 2.1$ & $-\$ 11.0$ & $-\$ 21.3$ \\
\hline Expenditures on Natural Gas, Residential & $\$ 0.0$ & $\$ 0.0$ & $\$ 0.0$ & $\$ 0.0$ \\
\hline Expenditures on Natural Gas, Commercial & $-\$ 0.9$ & $-\$ 37.5$ & $-\$ 281.8$ & $-\$ 574.7$ \\
\hline Expenditures on Electricity, Residential & $\$ 0.0$ & $\$ 0.0$ & $\$ 0.0$ & $\$ 0.0$ \\
\hline Expenditures on Electricity, Commercial & $-\$ 1.3$ & $-\$ 45.4$ & $-\$ 280.8$ & $-\$ 522.1$ \\
\hline Change in Energy Expenditures & $-\$ 2.2$ & $-\$ 85.0$ & $-\$ 573.6$ & $-\$ 1,118.0$ \\
\hline \multicolumn{5}{|l|}{ 4. Equipment Standards and Analysis } \\
\hline 603 & \multicolumn{4}{|c|}{ Equipment Standards and Analysis } \\
\hline 6043 & \multicolumn{4}{|c|}{ Standards: Res. Gas Furnaces/Boilers } \\
\hline Investment & $\$ 0.0$ & $\$ 26.4$ & $\$ 5.8$ & $-\$ 0.4$ \\
\hline Expenditures on Oil, Residential & $\$ 0.0$ & $\$ 0.0$ & $\$ 0.1$ & $\$ 0.2$ \\
\hline Expenditures on Oil, Commercial & $\$ 0.0$ & $\$ 0.0$ & $\$ 0.0$ & $\$ 0.0$ \\
\hline Expenditures on Natural Gas, Residential & $\$ 0.0$ & $-\$ 42.7$ & $-\$ 280.4$ & $-\$ 566.7$ \\
\hline Expenditures on Natural Gas, Commercial & $\$ 0.0$ & $\$ 0.0$ & $\$ 0.0$ & $\$ 0.0$ \\
\hline Expenditures on Electricity, Residential & $\$ 0.0$ & $\$ 0.3$ & $\$ 1.5$ & $\$ 3.7$ \\
\hline Expenditures on Electricity, Commercial & $\$ 0.0$ & $\$ 0.0$ & $\$ 0.0$ & $\$ 0.0$ \\
\hline Change in Energy Expenditures & $\$ 0.0$ & $-\$ 42.4$ & $-\$ 278.8$ & $-\$ 562.7$ \\
\hline 6044 & \multicolumn{4}{|c|}{ Standards: EPAct Standards } \\
\hline Investment & $\$ 205.0$ & $\$ 1,072.1$ & $\$ 1,473.7$ & $\$ 627.7$ \\
\hline Expenditures on Oil, Residential & $\$ 0.0$ & $\$ 0.0$ & $\$ 0.0$ & $\$ 0.0$ \\
\hline Expenditures on Oil, Commercial & $\$ 0.0$ & $\$ 0.0$ & $\$ 0.0$ & $\$ 0.0$ \\
\hline Expenditures on Natural Gas, Residential & $\$ 0.0$ & $\$ 0.0$ & $\$ 0.0$ & $\$ 0.0$ \\
\hline Expenditures on Natural Gas, Commercial & $\$ 0.0$ & $-\$ 22.0$ & $-\$ 102.5$ & $-\$ 176.6$ \\
\hline Expenditures on Electricity, Residential & $\$ 0.0$ & $\$ 0.0$ & $\$ 0.0$ & $\$ 0.0$ \\
\hline Expenditures on Electricity, Commercial & $-\$ 29.8$ & $-\$ 528.5$ & $-\$ 2,475.6$ & $-\$ 3,266.7$ \\
\hline Change in Energy Expenditures & $-\$ 29.8$ & $-\$ 550.5$ & $-\$ 2,578.1$ & $-\$ 3,443.3$ \\
\hline 6039 & \multicolumn{4}{|c|}{ Standards: Distribution Transformers } \\
\hline Investment & $\$ 0.0$ & $\$ 3,187.0$ & $\$ 3,767.2$ & $\$ 4,415.9$ \\
\hline Expenditures on Oil, Residential & $\$ 0.0$ & $\$ 0.0$ & $\$ 0.0$ & $\$ 0.0$ \\
\hline Expenditures on Oil, Commercial & $\$ 0.0$ & $\$ 0.0$ & $\$ 0.0$ & $\$ 0.0$ \\
\hline Expenditures on Natural Gas, Residential & $\$ 0.0$ & $\$ 0.0$ & $\$ 0.0$ & $\$ 0.0$ \\
\hline
\end{tabular}




\begin{tabular}{|c|c|c|c|c|}
\hline Expenditures on Natural Gas, Commercial & $\$ 0.0$ & $\$ 0.0$ & $\$ 0.0$ & $\$ 0.0$ \\
\hline Expenditures on Electricity, Residential & $\$ 0.0$ & $\$ 0.0$ & $\$ 0.0$ & $\$ 0.0$ \\
\hline Expenditures on Electricity, Commercial & $\$ 0.0$ & $-\$ 474.2$ & $-\$ 2,311.9$ & $-\$ 4,574.3$ \\
\hline Change in Energy Expenditures & $\$ 0.0$ & $-\$ 474.2$ & $-\$ 2,311.9$ & $-\$ 4,574.3$ \\
\hline \multicolumn{5}{|l|}{ Building Technologies Program } \\
\hline Investment & $\$ 805.4$ & $\$ 12,017.8$ & $\$ 16,216.7$ & $\$ 10,752.2$ \\
\hline Expenditures on Oil, Residential & $-\$ 3.2$ & $-\$ 64.2$ & $-\$ 474.7$ & $-\$ 1,108.6$ \\
\hline Expenditures on Oil, Commercial & $-\$ 0.2$ & $-\$ 8.7$ & $-\$ 74.3$ & $-\$ 106.6$ \\
\hline Expenditures on Natural Gas, Residential & $-\$ 15.8$ & $-\$ 445.2$ & $-\$ 3,146.7$ & $-\$ 6,200.2$ \\
\hline Expenditures on Natural Gas, Commercial & $-\$ 3.1$ & $-\$ 151.4$ & $-\$ 1,373.1$ & $-\$ 2,412.0$ \\
\hline Expenditures on Electricity, Residential & $-\$ 106.7$ & $-\$ 1,643.4$ & $-\$ 9,176.3$ & $-\$ 30,386.2$ \\
\hline Expenditures on Electricity, Commercial & $-\$ 68.9$ & $-\$ 1,428.1$ & $-\$ 9,903.3$ & $-\$ 20,618.5$ \\
\hline Change in Energy Expenditures & $-\$ 197.9$ & $-\$ 3,741.1$ & $-\$ 24,148.4$ & $-\$ 60,832.0$ \\
\hline
\end{tabular}


Table A.2. Allocation of EERE Building Technologies Subprogram Investment Costs by Sector

\begin{tabular}{|c|c|c|c|c|}
\hline Code & Name & $\begin{array}{l}\text { Maximum } \\
\text { Incremental } \\
\text { Investment } \\
\text { (2003\$/year) }\end{array}$ & Percent Distribution & Comments \\
\hline \multicolumn{5}{|c|}{ 1. Residential Buildings } \\
\hline 115 & $\begin{array}{l}\text { Research \& Development } \\
\text { (Building America) }\end{array}$ & $\$ 2,143.2$ & $\begin{array}{l}\text { 10\% each for Heating Equipment, Lighting Bulbs and } \\
\text { Tubes, and Electronic Components; 5\% each for } \\
\text { Residential Construction, Metal Doors etc., Household } \\
\text { Cooking, Household Refrigerators and Freezers, } \\
\text { Household Laundry, Electric Housewares and Fans, } \\
\text { Household Vacuum Cleaners, House Appliances Not } \\
\text { Elsewhere Classified, Other Lighting and Wiring, } \\
\text { Rubber and Plastic Products, Other Glass Products, } \\
\text { Cement, Lime and Gypsum, and Mineral Wool. }\end{array}$ & $\begin{array}{l}\text { Incremental investment as a result of the } \\
\text { program would be expected in residential } \\
\text { construction and in the manufacturing sectors } \\
\text { making the equipment and materials that would } \\
\text { achieve energy savings }\end{array}$ \\
\hline & $\begin{array}{l}\text { Residential Building } \\
\text { Energy Codes }\end{array}$ & $\$ 304.4$ & $\begin{array}{l}\text { Residential Construction 30\%; Heating Equipment } \\
\text { 30\%; Other Glass Products (windows) 20\%; Electronic } \\
\text { Components 10\%; Lighting Bulbs and Tubes 5\%; } \\
\text { Other Lighting and Wiring 5\%. }\end{array}$ & $\begin{array}{l}\text { Incremental investment as a result of the } \\
\text { program would be expected in residential } \\
\text { construction and in the manufacturing sectors } \\
\text { making the equipment and materials that would } \\
\text { be required by codes--mostly better windows } \\
\text { and improved lighting and climate and lighting } \\
\text { control. }\end{array}$ \\
\hline
\end{tabular}




\begin{tabular}{|c|c|c|c|c|}
\hline \multicolumn{5}{|c|}{ 2. Commercial Buildings Integration } \\
\hline 124 & Research \& Development & $\$ 5,567.4$ & $\begin{array}{l}\text { Commercial Construction 10\%; Electronic Components } \\
\text { 50\%; } 15 \% \text { each for Commercial Refrigeration and } \\
\text { Heating, Service Equipment; Lighting Bulbs and Tubes } \\
\text { 5\%; Other Lighting and Wiring 5\%. }\end{array}$ & $\begin{array}{l}\text { Incremental investment as a result of the } \\
\text { program would be expected in commercial } \\
\text { construction and in the manufacturing sectors } \\
\text { making the equipment and materials that would } \\
\text { achieve energy savings. Much of the } \\
\text { improvement would be expected in climate } \\
\text { control electronics. }\end{array}$ \\
\hline 507 & $\begin{array}{l}\text { Commercial Building } \\
\text { Energy Codes }\end{array}$ & $\$ 353.3$ & $\begin{array}{l}\text { Commercial Construction 30\%; 20\% Other Glass } \\
\text { Products (windows); Electronic Components 10\%; 15\% } \\
\text { each for Commercial Refrigeration and Heating, } \\
\text { Service Equipment; Lighting Bulbs and Tubes 5\%; } \\
\text { Other Lighting and Wiring 5\%. }\end{array}$ & $\begin{array}{l}\text { Incremental investment as a result of the } \\
\text { program would be expected in commercial } \\
\text { construction and in the manufacturing sectors } \\
\text { making the equipment and materials that would } \\
\text { be required by codes--mostly better windows } \\
\text { and improved lighting and climate and lighting } \\
\text { control. }\end{array}$ \\
\hline \multicolumn{5}{|c|}{ 3. Emerging Technologies } \\
\hline \multicolumn{5}{|c|}{ 430 Lighting R\&D } \\
\hline 4304 & Lighting R\&D: Controls & $\$ 113.1$ & Electronic components $100 \%$ & $\begin{array}{l}\text { This sector is the manufacturing sector for the } \\
\text { advanced equipment }\end{array}$ \\
\hline 440 & Solid State Lighting & $\$ 63.3$ & $\begin{array}{l}\text { Lighting Bulbs and Tubes 50\%; Other Lighting and } \\
\text { Wiring 50\% }\end{array}$ & $\begin{array}{l}\text { These sectors are the manufacturing sectors for } \\
\text { the advanced (mostly solid-state) lighting } \\
\text { equipment }\end{array}$ \\
\hline 380 & \multicolumn{2}{|c|}{ Space Conditioning \& Refrigeration R\&D } & & \\
\hline 3801 & $\begin{array}{l}\text { Refrigeration R\&D: Res. } \\
\text { HVAC Dist. System }\end{array}$ & $\$ 76.8$ & 3 Residential (and Light Commercial) Construction 100\% & $\begin{array}{l}\text { This program is mostly focused on } \\
\text { improvements in the construction of residential } \\
\text { buildings, including appropriate equipment } \\
\text { purchases by contractors }\end{array}$ \\
\hline 3802 & $\begin{array}{l}\text { Refrigeration R\&D: Adv. } \\
\text { Elec. HPWH }\end{array}$ & $\$ 296.7$ & 7 Household Appliances, Not Elsewhere Classified 100\% & $\begin{array}{l}\text { This sector is the manufacturing sector for the } \\
\text { advanced equipment }\end{array}$ \\
\hline
\end{tabular}




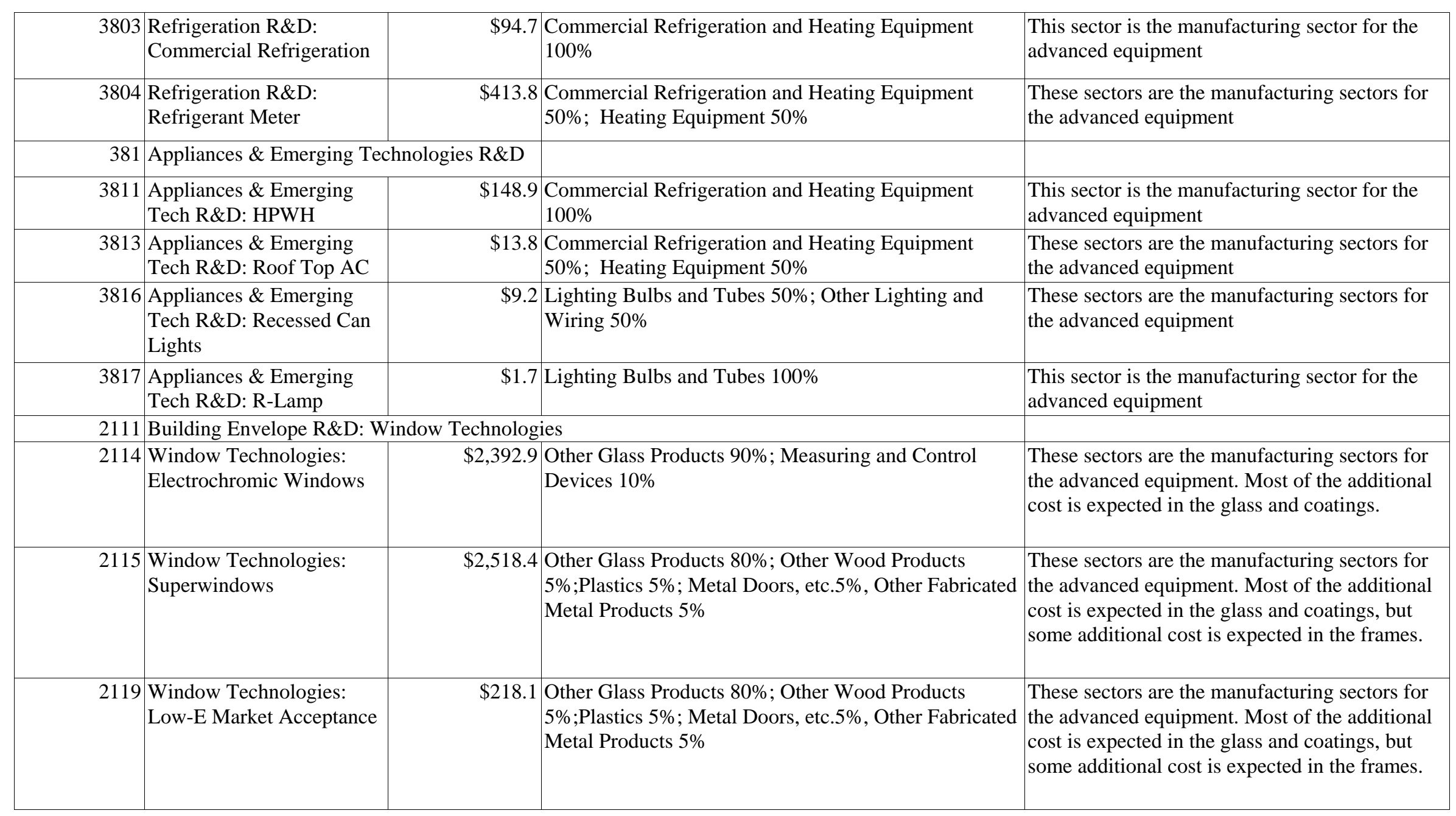




\begin{tabular}{|r|r|l|l|l|}
\hline 145 & Analysis Tools and Design & & $\begin{array}{l}\text { \$99.9 } \\
\text { Residential Construction 20\%; Heating Equipment } \\
30 \% ; 10 \% \text { each for Lighting Bulbs and Tubes and } \\
\text { Other Lighting and Wiring; 5\% each for Household } \\
\text { Cooking, Household Refrigerators and Freezers, } \\
\text { Household Laundry, Electric Housewares and Fans, } \\
\text { Household Vacuum Cleaners, and Household } \\
\text { Appliances Not Elsewhere Classified. }\end{array}$ & $\begin{array}{l}\text { A broad array of sectors involved in residential } \\
\text { construction and equipment is expected to be } \\
\text { affected, with most of the impact on } \\
\text { construction, heating plant, and lighting. }\end{array}$ \\
\hline 6043 & $\begin{array}{l}\text { Standards: Res. Gas } \\
\text { Furnaces/Boilers }\end{array}$ & $\begin{array}{l}\text { This sector is the manufacturing sector for the } \\
\text { advanced equipment }\end{array}$ \\
\hline 6044 & $\begin{array}{l}\text { Standards: EPAct } \\
\text { Standards }\end{array}$ & $\begin{array}{l}\text { This sector is the manufacturing sector for the } \\
\text { advanced equipment }\end{array}$ \\
\hline 6039 & $\begin{array}{l}\text { Standards: Distribution } \\
\text { Transformers }\end{array}$ & $\begin{array}{l}\text { These sectors are the manufacturing sectors for } \\
\text { the advanced equipment }\end{array}$ \\
\hline
\end{tabular}




\section{Distribution}

No. of

Copies

\section{OFFSITE}

Michael McCabe (3)

U.S. Department of Energy

EERE-Building Technologies

Program (EE-2J)

1000 Independence Ave., S.W.

Washington, DC 20585

John D. Ryan

U.S. Department of Energy

EERE-Building Technologies

Program (EE-2J)

1000 Independence Ave., S.W.

Washington, DC 20585

Jim Rannells

U.S. Department of Energy

EERE-Building Technologies

Program (EE-2J)

1000 Independence Ave., S.W.

Washington, DC 20585

Ed Pollock

U.S. Department of Energy

EERE-Building Technologies

Program (EE-2J)

1000 Independence Ave., S.W.

Washington, DC 20585

Brian Card

U.S. Department of Energy

EERE-Office of Planning, Budget and Analysis

(EE-3B)

1000 Independence Ave., S.W.

Washington, DC 20585

Qonnie Laughlin

U.S. Department of Energy

EERE-Building Technologies

Program (EE-2J)

1000 Independence Ave., S.W.

Washington, DC 20585
Bryan Berringer

U.S. Department of Energy

EERE-Building Technologies

Program (EE-2J)

1000 Independence Ave., S.W.

Washington, DC 20585

Richard Orrison

U.S. Department of Energy

EERE-Building Technologies

Program (EE-2J)

1000 Independence Ave., S.W.

Washington, DC 20585

Jim Brodrick

U.S. Department of Energy

EERE-Building Technologies

Program (EE-2J)

1000 Independence Ave., S.W.

Washington, DC 20585

Sam Baldwin

U.S. Department of Energy

EERE-Board of Directors (EE-11)

1000 Independence Avenue, S.W.

Washington, DC 20585

Darrell Beschen

U.S. Department of Energy

EERE-Office of Planning, Budget and Analysis (EE-

3B)

1000 Independence Avenue, S.W.

Washington, DC 20585

David Boomsma

U.S. Department of Energy

EERE-Office of Planning, Budget and Analysis (EE-

3B)

1000 Independence Avenue, S.W.

Washington, DC 20585

Pat Booher

U.S. Department of Energy

EERE-Office of Planning, Budget and Analysis (EE-

3B)

1000 Independence Avenue, S.W.

Washington, DC 20585 
PNNL-14813

Jerry Dion

U.S. Department of Energy

EERE-Building Technologies

Program (EE-2J)

1000 Independence Avenue, S.W.

Washington, DC 20585

Jeff Dowd

U.S. Department of Energy

EERE-Office of Planning, Budget and Analysis

(EE-3B)

1000 Independence Avenue, S.W.

Washington, DC 20585

Mike Gonzalez

U.S. Department of Energy

EERE-Office of Planning, Budget and Analysis

(EE-3B)

1000 Independence Avenue, S.W.

Washington, DC 20585

Tien Nguyen

U.S. Department of Energy

EERE-Office of Planning, Budget and Analysis

(EE-3B)

1000 Independence Avenue, S.W.

Washington, DC 20585

Phil Patterson

U.S. Department of Energy

EERE-Office of Planning, Budget and Analysis

(EE-3B)

1000 Independence Avenue, S.W.

Washington, DC 20585

Peggy Podolak

U.S. Department of Energy

EERE-Office of Planning, Budget and Analysis

(EE-3B)

1000 Independence Avenue, S.W.

Washington, DC 20585

Linda Silverman

U.S. Department of Energy

EERE-Building Technologies

Program (EE-2J)

1000 Independence Avenue, S.W.

Washington, DC 20585
Randy Steer

U.S. Department of Energy

EERE-Office of Planning, Budget and Analysis (EE-

3B)

1000 Independence Avenue, S.W.

Washington, DC 20585

Brian Unruh

U.S. Department of Energy

EERE-Office of Planning, Budget and Analysis (EE-

3B)

1000 Independence Avenue, S.W.

Washington, DC 20585

Michael York

U.S. Department of Energy

EERE-Office of Planning, Budget and Analysis (EE-

3B)

1000 Independence Avenue, S.W.

Washington, DC 20585

Ed Barbour

Navigant Consulting

1801 K Street, NW

Suite 500

Washington, D.C. 20006

M.D. Levine

Ernest Orlando Lawrence Berkeley National

Laboratory

1 Cyclotron Road, 90-R3027D

Berkeley, CA 94720

T. Chan

Ernest Orlando Lawrence Berkeley National Laboratory

1 Cyclotron Road, 90-R4000

Berkeley, CA 94720

L.L. Dale

Ernest Orlando Lawrence Berkeley National Laboratory

1 Cyclotron Road, 90-R4000

Berkeley, CA 94720 
Jeff Harris

Ernest Orlando Lawrence Berkeley National Laboratory

901 D Street

$9^{\text {th }}$ Floor

Washington, DC 20024-2115

W. Short

National Renewable Energy Laboratory

617 Cole Boulevard, Mail Stop 2721

Golden, CO 80401-3393

M.A. Brown

Oak Ridge National Laboratory

P.O. Box 2008, Mail Stop 6186

Oak Ridge, TN 37831-6186

R. Lee

Oak Ridge National Laboratory

P.O. Box 2008, Mail Stop 6205

Oak Ridge, TN 37831-6205

H. Geller

Executive Director

American Council for an Energy-Efficient Economy

1001 Connecticut Avenue, N.W.,

Suite 801

Washington, DC 20036

D. M. Nemtzow

Alliance to Save Energy

$120018^{\text {th }}$ Street, N.W.

Suite 900

Washington, DC 20036

John “Skip” Laitner

U.S. Environmental Protection Agency

1200 Pennsylvania Avenue, N.W.

Washington, DC 20460
No. of

$\underline{\text { Copies }}$

ONSITE

2 DOE Richland Operations Office

D. L. Biancosino K8-50

35 Pacific Northwest National Laboratory

D. M. Anderson K5-06

R. Bartlett K5-02

D. B. Belzer K5-06

K. A. Cort K5-06

J. A. Dirks K6-10

D. B. Elliott Portland/1/OS

E. M. Fathelrahman K5-06

D. J. Hostick K5-06

B. R. Kinzey BWO

S. C. McDonald (10) BWO

A. K. Nicholls BWO

L. A. Stevenson Offsite/MA/OS

J. M. Roop K5-06

L. J. Sandahl Portland/1/OS

B. F. Saffell K5-02

L. J. Sealock K5-02

M. J. Scott (5) K5-06

S. A. Shankle K5-16

R.W. Schultz K6-10

T. M. Weber K5-06

Info Release Office (2) K1-06 